\title{
THE KARREN PEELING OFF ON MARBLES IN ALTAI (ALTAI REPUBLIC, RUSSIAN FEDERATION)
}

\author{
LUŠČENJE ŠKRAPELJ NA MARMORJIH V ALTAJU \\ (ALTAJSKA REPUBLIKA, RUSKA FEDERACIJA)
}

\author{
Martin KNEZ ${ }^{1,2,3^{*}}$, Tadej SLABE ${ }^{1,2,3}$, Mirka TRAJANOVA ${ }^{4}$, \\ Tatiana AKIMOVA ${ }^{5} \&$ Igor KALMYKOV ${ }^{5}$
}

\begin{abstract}
UDC 551.435.81:552.46(235.222)

Martin Knez, Tadej Slabe, Mirka Trajanova, Tatiana Akimova \& Igor Kalmykov: The karren peeling off on marbles in Altai (Altai Republic, Russian Federation)

A comparison of karren formation on various rocks under diverse environmental conditions makes an important contribution to our understanding of the formation and development of karst. In this regard, the present study brings a number of new insights through description of the karst development on marbles at the foothills of the Altai Mountains. We studied karst phenomena in the field and in laboratory where structural-textural properties, mineral composition and quantity of carbonate components were determined. Rivers dissected karst surface and additionally uncovered carbonate rocks. The marble layers are faulted, folded and sheared, consequently containing numerous densely spaced net of discontinuities, which are often parallel. Brittle deformations significantly increased the rocks' porosity, consequently making it more sensitive to water absorption and freezing thaw effect. Distinct continental climate, with extreme daily and seasonal temperature variations, conditions the pronounced peeling off of the marbles along discontinuities. The diversity of disintegration is conditioned by the massive or oriented structure, cleavage, texture, and type and grainsize of the marbles' mineral constituents. Interaction and alternation of chemical dissolution and mechanical disintegration play the major role on the karren formation and its preservation. The formed karren is mostly destroyed due to peeling off and disintegration of the marbles.

Key words: karren, marble, structure, texture, complexometry, rock relief, Altai.

Izvleček UDK 551.435.81:552.46(235.222)
Martin Knez, Tadej Slabe, Mirka Trajanova, Tatiana Akimo-
va in Igor Kalmykov: Luščenje škrapelj na marmorjih v Altaju
(Altajska republika, Ruska federacija)

Primerjava oblikovanja škrapelj na različnih kamninah v različnih okoljskih razmerah pomembno prispeva k razumevanju oblikovanja in razvoja krasa. Ta prispevek s prikazom razvoja krasa na marmorju z vznožja Altajskega gorovja prinaša številne novosti. Kraške oblike smo proučevali na terenu in v laboratoriju, pri čemer smo določili teksturno-strukturne lastnosti, mineralno sestavo in količino karbonatnih komponent. Reke so razčlenile površje in še dodatno razkrile karbonatne kamnine. Plasti marmorja sekajo številni prelomi in razpoke, so nagubane in strižno deformirane, zato vsebujejo gosto mrežo diskontinuitet, ki so pogosto vzporedne. Lomne deformacije so močno povečale poroznost kamnine, zato je ta bolj dovzetna za absorpcijo vode ter na učinke zmrzovanja in tajanja. Izrazito kontinentalno podnebje $\mathrm{z}$ ekstremnimi dnevnimi in sezonskimi temperaturnimi nihanji vpliva na razpadanje marmorja ob diskontinuitetah. Raznolikost razpadanja je večinoma posledica masivne ali orientirane teksture, klivaža, strukture ter vrste in zrnavosti mineralnih sestavin. Glavno vlogo pri nastanku škrapelj in njihovem ohranjanju imata medsebojno delovanje ter izmenjava kemičnega raztapljanja in mehaničnega razpadanja. Nastale škraplje so večinoma uničene zaradi luščenja in razpadanja marmorjev.

Ključne besede: škraplje, marmor, struktura, tekstura, kompleksometrija, skalni relief, Altaj.

${ }^{1}$ Research Centre of the Slovenian Academy of Sciences and Arts, Karst Research Institute, Titov trg 2, SI-6230 Postojna, Slovenia, e-mails:knez@zrc-sazu.si, slabe@zrc-sazu.si

${ }^{2}$ UNESCO Chair on Karst Education, University of Nova Gorica, Glavni trg 8, 5271 Vipava, Slovenia, e-mails: knez@zrc-sazu.si, slabe@zrc-sazu.si

${ }^{3}$ Yunnan University International Joint Research Center for Karstology, Xueyun rd. 5, CN-650223, Kunming, China, e-mails: knez@zrc-sazu.si, slabe@zrc-sazu.si

${ }^{4}$ Geological Survey of Slovenia, Dimičeva ulica 14, SI-1000 Ljubljana, Slovenia, e-mail: Mirka.Trajanova@GEO-ZS.SI

${ }^{5}$ Altaisky State Nature Biosphere Reserve, Naberezhny lane 1, RU-649000 Gorno-Altaisk, Altai Republic, Russian Federation, e-mails: vdovina-ta@mail.ru,kalmyk1961@mail.ru

* Corresponding author
\end{abstract}

Received/Prejeto: 29.12.2018

DOI: $10.3986 /$ ac.v49i1.7197 


\section{INTRODUCTION}

Comparative studies of karst geology, forms, and the rock relief of karst phenomena reveal their respective development and deepen our knowledge about the karst formation on different carbonate rocks in diverse conditions of the world (Knez et al. 2003, 2010, 2011, 2012, 2015, 2017, 2019; Debevec et al. 2012; Al Faraj Al Ketbi et al. 2014; Gutiérrez Domech et al. 2015; Slabe et al. 2016).

We studied origin of karst phenomena developed on marmorized carbonate rocks denuded by the rivers Katun and Chuya as they cut into the diverse lithological units of the Altai Mountains foothills in Gorny Altai (Russian Federation). The marmorized carbonate rocks belong to the Late Paleozoic tectonic nappes of the Altai-Sayan area, which is a complex aggregate of units of different geodynamic affinity (e.g., Ota et al. 2007; Buslov et al. 2013). The Gorny Altai geological conditions show its very complex structure, formed in the suture-shear zone between the composite Kazakhstan-Baikal continent and Siberia (Ota et al. 2007; Turkin et al. 2004; Buslov et al. 2013). The Late Cambrian fold-nappe structures within the Biya-Katun and Kurai zones are overlain by the fore-arc basin rocks unit and Ordovician-Early Devonian carbonate and terrigenous passive-margin rocks of the Anyui-Chuya zone, which is composed of Middle Cambrian to Early Ordovician fore-arc basin rocks (Buslov et al. 2013). The rocks are strongly metamorphosed. The position of the studied
Katun and Chuya area in this complex geodynamic region is the reason for intensely deformed rocks. Due to a strong dynamometamorphism, they were often retrogressed from higher to lower metamorphic grade.

The aim of our study is to unravel causes for the pattern of marbles' disintegration through their macro- and micro-structural and textural properties, and mineral composition, together yielding their typical karst morphology.

The research includes the areas of marmorized carbonate rocks of the Ak-Kaya, Chuya and Ak-Bom (Fig. 1). The picturesque landscape in marble was formed by intensive tectonic activity. The relief is additionally reshaped by surface processes including mechanical and water erosion as well as corrosion.

Detailed geological survey was performed in a selected cross-section of stone pillars of the Ak-Kaya Valley: measurements and studies of rock characteristics from the viewpoint of lithology, petrology, and stratigraphy, and measurements of tectonic and microtectonic elements. Marmorized carbonates, predominantly marmorized limestone, were identified.

Field work is presented in the documentary film Krasni kras made by the Slovenian national TV broadcaster (https://4d.rtvslo.si/arhiv/dokumentarni-filmi-in-oddaje-izobrazevalni-program/174606101)

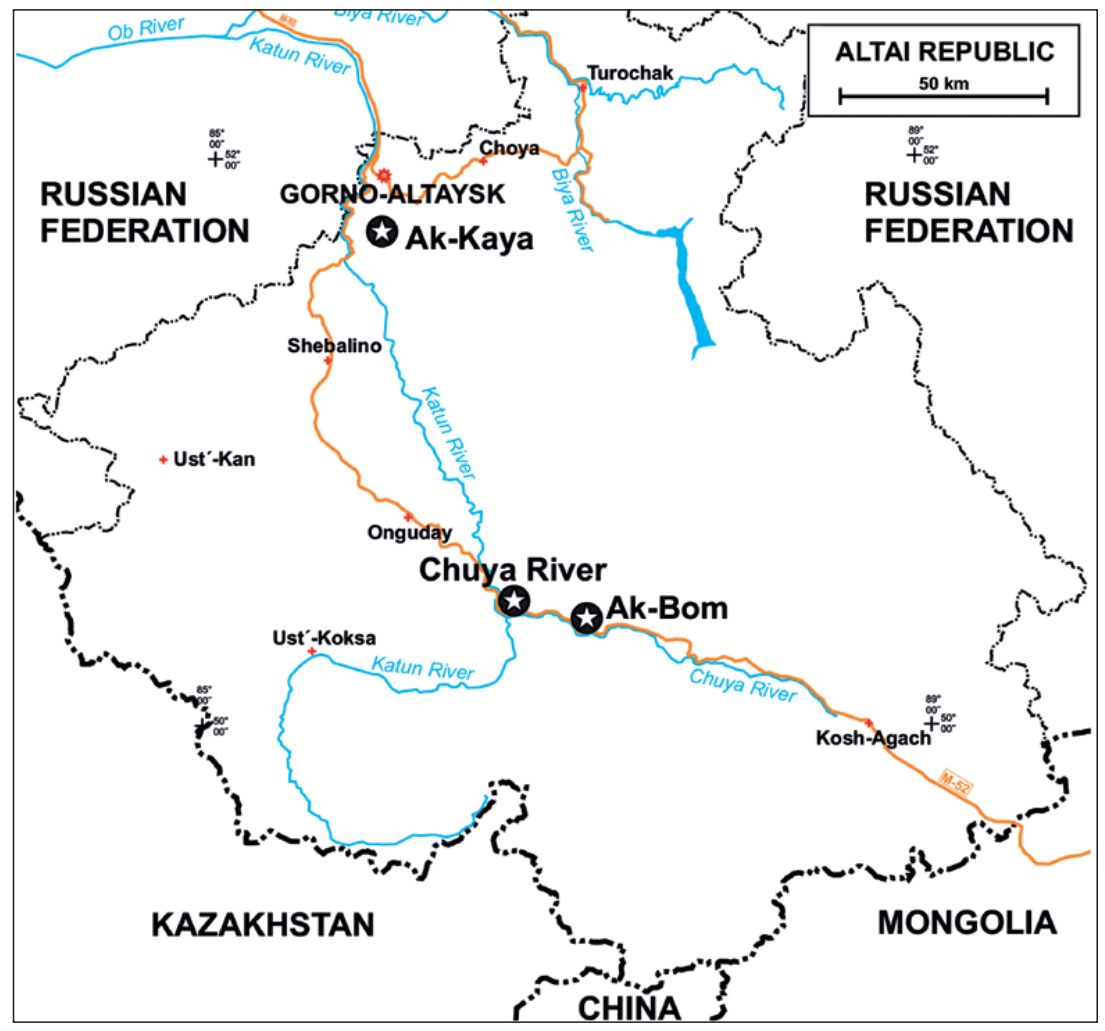

Fig. 1: Location map of research areas: $A k$ Kaya Valley, Ak-Bom, the confluence of the Chuya and Katun rivers. 


\section{CHARACTERISTICS OF THE STUDIED MARBLES}

Broadly, two types of marbles are determined in the study area: massive and purer one with little or no admixtures, and platy and foliated one with abundant non-carbonate admixtures. The first type forms macroscopically gentle folds of at least dekameter size. Their color is white to yellowish or grayish white. They contain frequent stylolite seams, indicating pressure solution effect. The second type has platy structure with distinct compositional layering. Silicate admixtures give the rock greenish white to pale green color. The massive marbles originate mostly from relatively pure, rarely partly brecciated limestone, which locally contains chert. Layered marble probably originated from impure limestone, containing thin beds and/or laminae of tuff (Buslov et al. 2013).

Marbles outcrops, ranging in size from several tens to several hundreds of square meters, occur between impermeable rocks, shown on the geological map (Turkin et al. 2004). In the near-surface parts, the marbles are mostly mechanically disintegrated, locally densely fissured, and strongly crushed.

The mineral assemblage of white mica, chlorite, quartz, \pm tremolite-actinolite, \pm albite belongs to the low level of regional metamorphism in the lower to middle part of the greenschist facies. Multi-phase deformations thus preceded as well as followed the metamorphism of the parent limestone. From brittle deformations, they moved to plastic deformations with localized mylonitization and cataclasis and then back to brittle, which indicates their subduction and subsequent uplift. Dynamometamorphism is visible primarily as shear deformations. Foliation, cleavage, intergranular micro-fractures, and opened fissures occur as well as frequent irregular interchange of different rock types. The pronounced heterogranular texture of some of the marbles is the consequence of partial disintegration of numerous coarsegrained calcite veins in them. The direction of cleavage is the dominant direction of the rocks' peeling off.

Due to the properties of the rock and its exposure to harsh climate conditions with pronounced temperature fluctuations, disintegration plays a very important role in the karren formation.

With the presence of moisture, they are sensitive to the large temperature oscillations in the characteristic continental climate due to freezing in the winter, and thawing and high temperatures in the summer. The rapid disintegration of marbles is therefore mainly the consequence of mechanical disintegration and subordinately of classic karstification due to water erosion and corrosion.

In the selected cross-section of stone pillars of the
Ak-Kaya Valley, the unique rock relief reveals the manner of vertical and thin layers of rock formation that are decomposed and transformed by water flowing from the tops. The water also permeates along cleavage fissures and three-dimensionally shapes the karren. Inclined walls beneath the soil-covered and denuded tops are characteristically shaped. Biocorrosion is an important factor of rock formation.

The Ak-Kaya Valley is located in the upper reaches of the Maima River in the Iolginsky Physical-Geographic Region of the Northeastern Altai Province, $7 \mathrm{~km}$ southwest of the Biryulya village of the Maiminsky District of the Altai Republic (Figs. 1-2). The valley is located in a zone of low-altitude montane forest landscapes with pine-fir-birch forests and meadows on mountainforest and dark-gray soils. The climate of the region is extremely continental with a short hot summer and a long cold winter. The average annual air temperature is $+1{ }^{\circ} \mathrm{C}$, in January it is $-16{ }^{\circ} \mathrm{C}$, and in July, $+19-22^{\circ} \mathrm{C}$. The average annual precipitation is $720-730 \mathrm{~mm}$; the greatest amount falls in the warm season. Geologically, this territory belongs to the northern part of the Katun structural and formation block composed of Upper Proterozoic-Cambrian carbonate and basalt formations. In hydrogeological terms, this territory relates to the northern part of the Katun hydrogeological block with a complex of underground waters of vein, fissure, and karst type (Marinin 1990). The relief here is sharply dissected by the low mountain range. The steepness of the slopes of the mountain is $15^{\circ}-25^{\circ}$. The height of the terrain varies between 580 and 840 meters a.s.l.

The unique formation of the denuded rock surface of karren with disintegration of the rock due to high temperature oscillation in the Chuya Valley above AkBom (Fig. 1; Fig. 16) is described here for the first time. The karren formed on calcite marbles with a variable content of silicate admixtures. Our findings are based on the integration of lithological, petrographic, structural and morphological research of the rock relief.

The Ak-Bom Massif is located on the right bank of the Chuya River near the Ak-Bom village in the Ongudaysky District of the Altai Republic. In the geological structure of the region, there is the foundation of the southern half of the ancient Katunsky protrusion (anticlinorium). It is composed of dislocated and metamorphosed rock of the Middle and Upper Ordovician. Metamorphosed shale, sandstone, and siltstone alternate with massive marbles (Marinin 1990). The relief is characterized by the depth and steepness of the dissection between 700 and 1,000 meters a.s.l. The climate is continental, characterized by significant tem- 
perature fluctuations during the day reaching $20^{\circ} \mathrm{C}$ to $30{ }^{\circ} \mathrm{C}$. Precipitation is moderate. The average January temperature is $-15^{\circ} \mathrm{C}$ and in July, $+18^{\circ} \mathrm{C}$. Snow cover is observed up to 100 days but its height reaches no more than $10 \mathrm{~cm}$. The amount of annual precipitation is up to $260 \mathrm{~mm}, 70 \%$ of which falls in the warm period of the year. The landscape is formed mainly of mountain-steppe and mountain-forest complexes. Larch forests with grass, steppe and shrub species cover its slopes.

The confluence of the Chuya and Katun Rivers is located $30 \mathrm{~km}$ northwest of the Ak-Bom Massif (Fig.1). The majority of the lower rocky slope of the mountain above the confluence (Fig. 27) is relatively rounded and smooth, representing the trace of formation under alluvial sediment, while the denuded slope is distinctly marked by mechanical disintegration and peeling off. The rock plates cover a surface of several square meters and split along cleavage surfaces.

The morphological characteristics of the marbles under these climate conditions are demonstrated, and the unique development of karren revealed from underneath sediment and soil is described for the first time.

The characteristics of karst in the Altai Republic have been described by Marinin (1990).

\section{LITHOLOGICAL CHARACTERISTICS AND ROCK RELIEF OF ROCK PILLARS IN THE AK-KAYA VALLEY}

\section{SHAPE OF ROCK PILLARS}

The northern slope of the Ak-Kaya Valley (Figs. 1-2) is dissected by rock pillars (Figs. 3-4). Wide pillars, whose diameters often exceed ten meters, reach heights of twenty meters. In most cases they are grouped in clusters, many together on ridges or on slopes. According to the geological structure, they dissect the slope perpendicularly in some areas. Individual and smaller pillars are distributed mostly on the ridge of a slope. Wide rock pillars dominate but all of them gradually narrow toward the top. The wider tops are often dissected into several smaller ones. In places, the manner of the three-dimensional formation has preserved their partly rounded shape. The walls are formed in parallel with thin vertical layers (Fig. 5a in Appendix; Figs. 5-6 in Ap- pendix; Figs. 8-15 in Appendix) or transverse layers. In parallel formations, the shape is dictated by uniform or stepped scaling of the rock. The lower sections are often distinctly wider. Walls formed with transverse peels are often steep, dissected by steps, and rarely overhanging (Fig. 5b in Appendix). Only individual walls are vertical. Wide tops are covered by soil and overgrown with trees and shrubbery, and their gentler slopes are also covered with smaller vegetation. The pillars are of subsoil origin and thus denuded or transformed beneath the soil and vegetation that still covers the rock locally. In some places, the pillars are perforated by smaller, mostly subsoil co-formed caves whose diameters reach one meter in size.

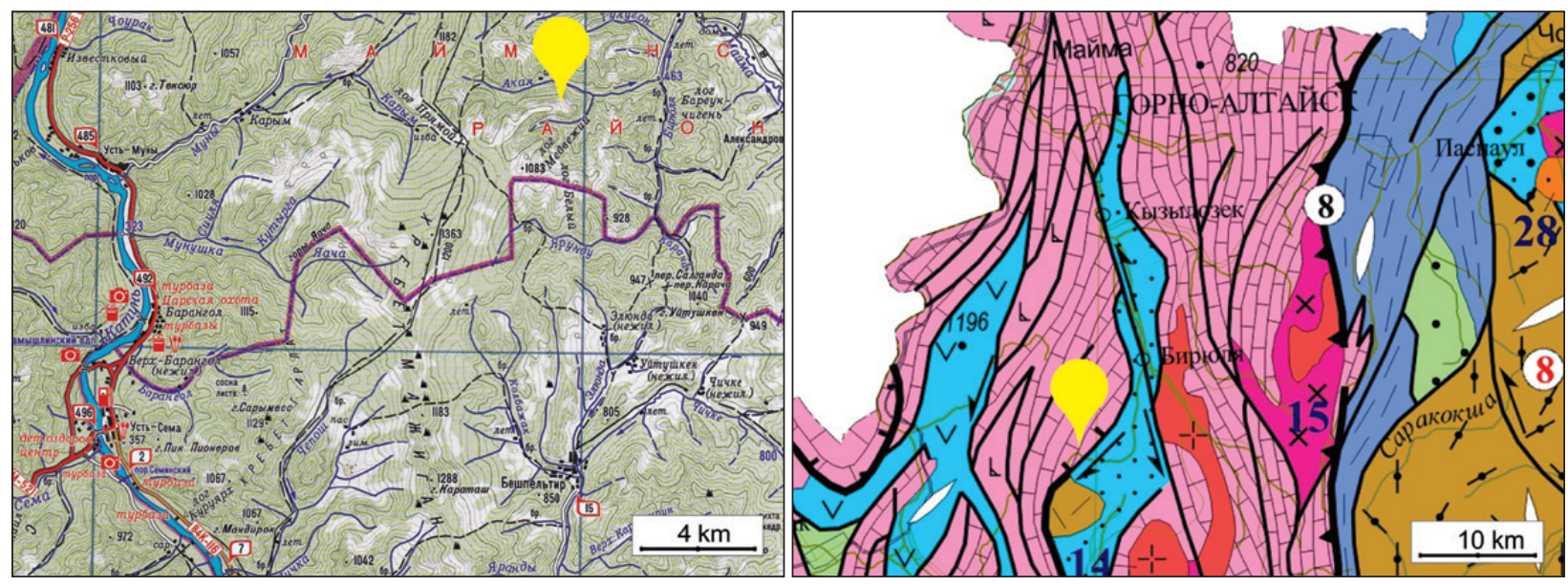

Fig. 2: Left: topographic map (Valiy \& Strebkov 2018) of the research point in the Ak-Kaya Valley. Right: geological map (Turkin et al. 2010) of the research point in the Ak-Kaya Valley, carbonates in pink color. 


\section{GEOLOGY}

The rocks from the Ak-Kaya Valley testify of the turbulent tectogenetic evolution of their parent rocks. According to the Munsell Rock-Color Chart (2009), they belong to the medium grey (N6 to N4) types of very fine-grained marble, containing a dense net of white veins of several generations. All the investigated samples were intensely altered by dynamometamorphic processes. They were subjected to mylonitization, due to which the mineral grains are ductile deformed and intensely degradationally recrystallized. Pronounced foliation evolved, governing the preferred direction of the rock's peeling off. Infrequent veins trend transversely to the foliation.

It was possible to confirm four generations of veins in the thin sections. The first generation is composed of quartz and calcite or only of quartz, and was the coarsest grained. These veins were formed prior to mylonitization and are not preserved in an intact state. Only isolated strongly deformed porphyroclasts of bigger calcite grains (Fig. 6a in Appendix) and quartz with pronounced undulate extinction (Figs. 6b-c in Appendix) can be observed in the thin sections. They are arranged along the foliation, producing a blastomylonitic texture (Fig. 6b in Appendix). Every subsequent generation of the calcite veins is somewhat less deformed, which indicates that the veins were formed syndeformationally but after mylonitization (Figs. 6d-e in Appendix). Stylolites formed in mylonite as the result of the pressure dissolution. They contain concentrated insoluble residues and were subsequently partly infilled by calcite (Figs. 6d-e in Appendix).

Some samples contain a higher quantity of quartz that does not originate from veins. It is very fine grained, progressively recrystallized, and usually intimately interwoven with calcite (Fig. 6d in Appendix; Fig. 6f in Appendix). Its origin could be attributed to the presence of chert nodules in the parent limestone.

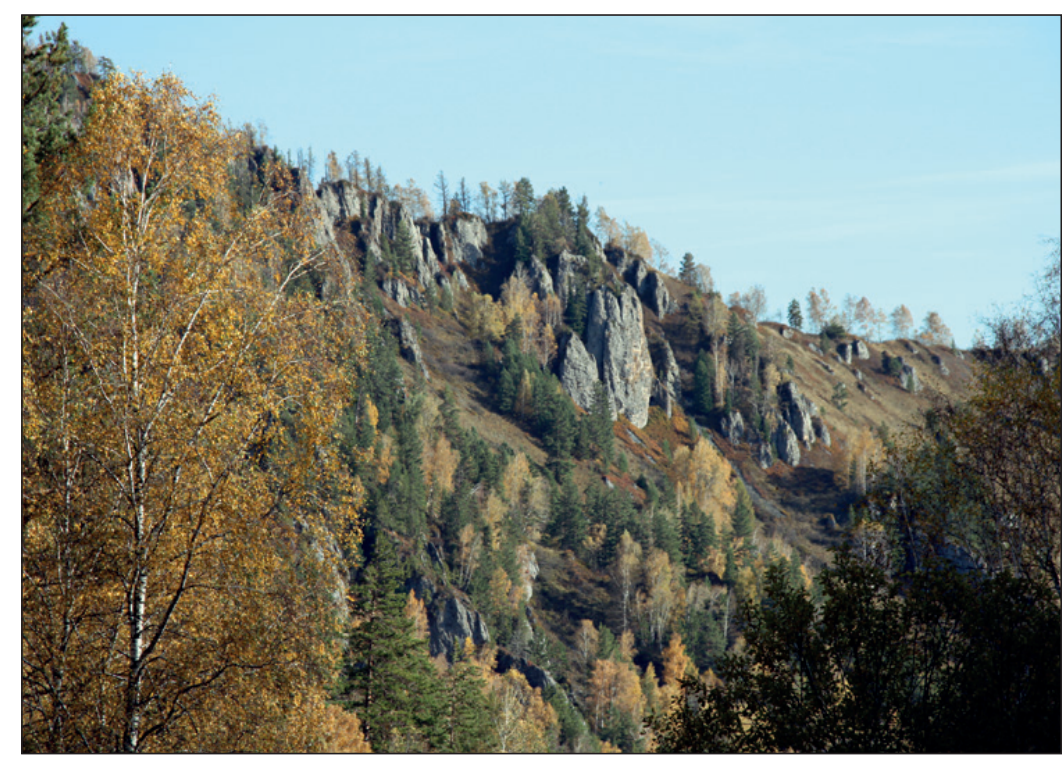

Fig. 3: The northern slope of the Ak-Kaya Valley (Photo: M. Knez).

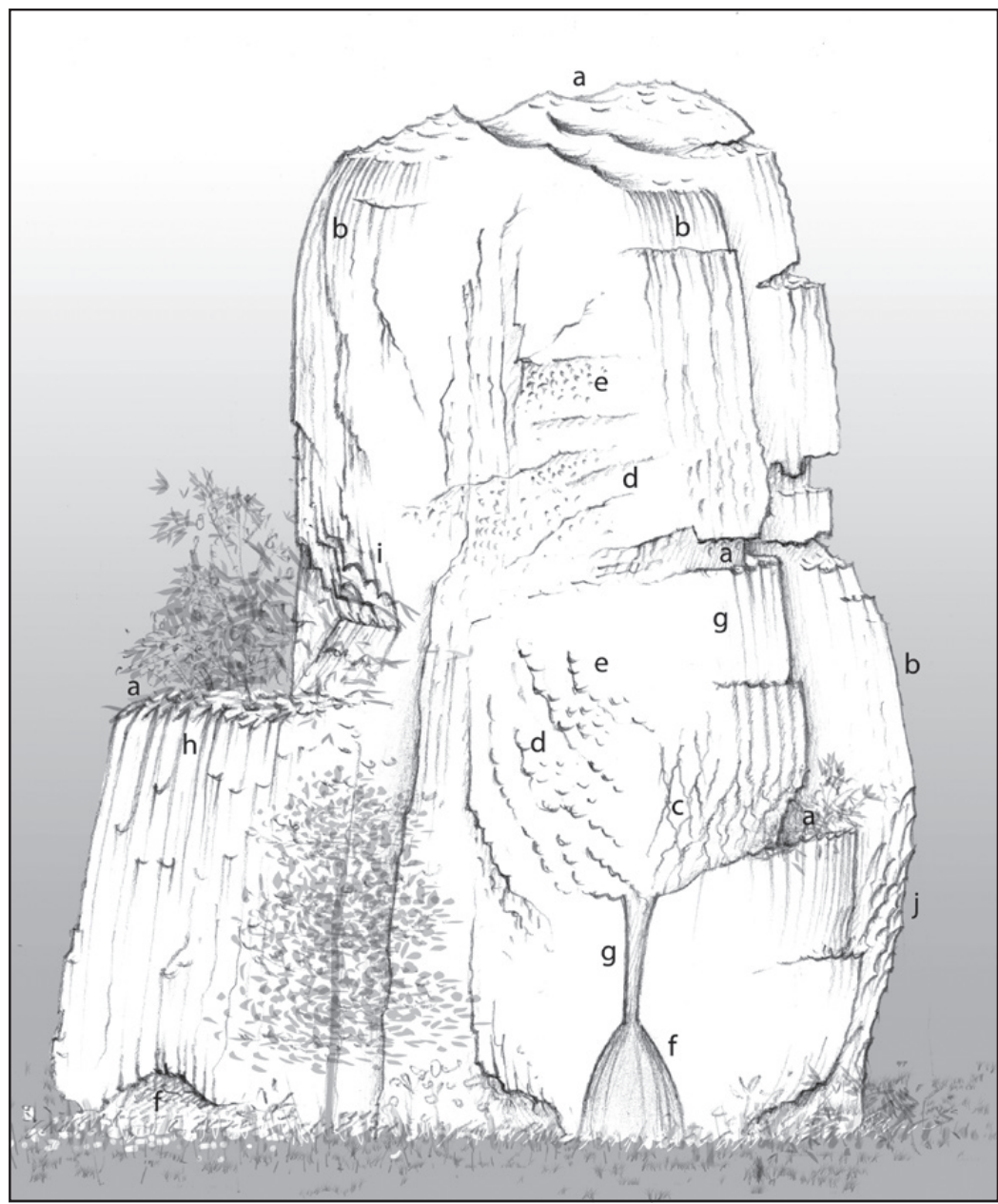

Fig. 4: Karren on marble, Ak-Kaya: a. subsoil cups and channels, b. rain flutes, c. bedding plane channels, d. steps, e. pits, f. subsoil half-bell, $g$. wall channel, $h$. wall channel below a shelf, $i$. ceiling cup, j. rain scallops. A stone pillar is $20 \mathrm{~m}$ high. 


\section{COMPLEXOMETRIC TITRATION ANALYSES}

Using the dissolving method (Engelhardt et al. 1964), we performed 17 complexometric titration analyses on 17 rock samples (Tab. 1; Fig. 7). The range of carbonate content in the samples varies from $>24 \%$ to $99 \%$. Three samples do not reach $50 \%$ total carbonate. Above $90 \%$ total carbonate was measured in ten samples, which is more than half, and the average of all samples almost reaches $80 \%$ total carbonate. The range of calcite content also varies from more than $23 \%$ to almost $98 \%$. Four samples do not reach $50 \%$ calcite. Above $90 \%$ calcite was measured in eight samples and the average value reaches $77 \%$. All of the samples also contain a significant proportion of dolomite. One sample contains over $14 \%$. Ten samples have less than $2 \%$ dolomite, five less than $1 \%$, and only two between $3 \%$ and $4 \%$. The average value is just $2.4 \%$, but if the sample with $14.2 \%$ dolomite is excluded, the average is only $1.7 \%$. Insoluble residue varies evenly and in

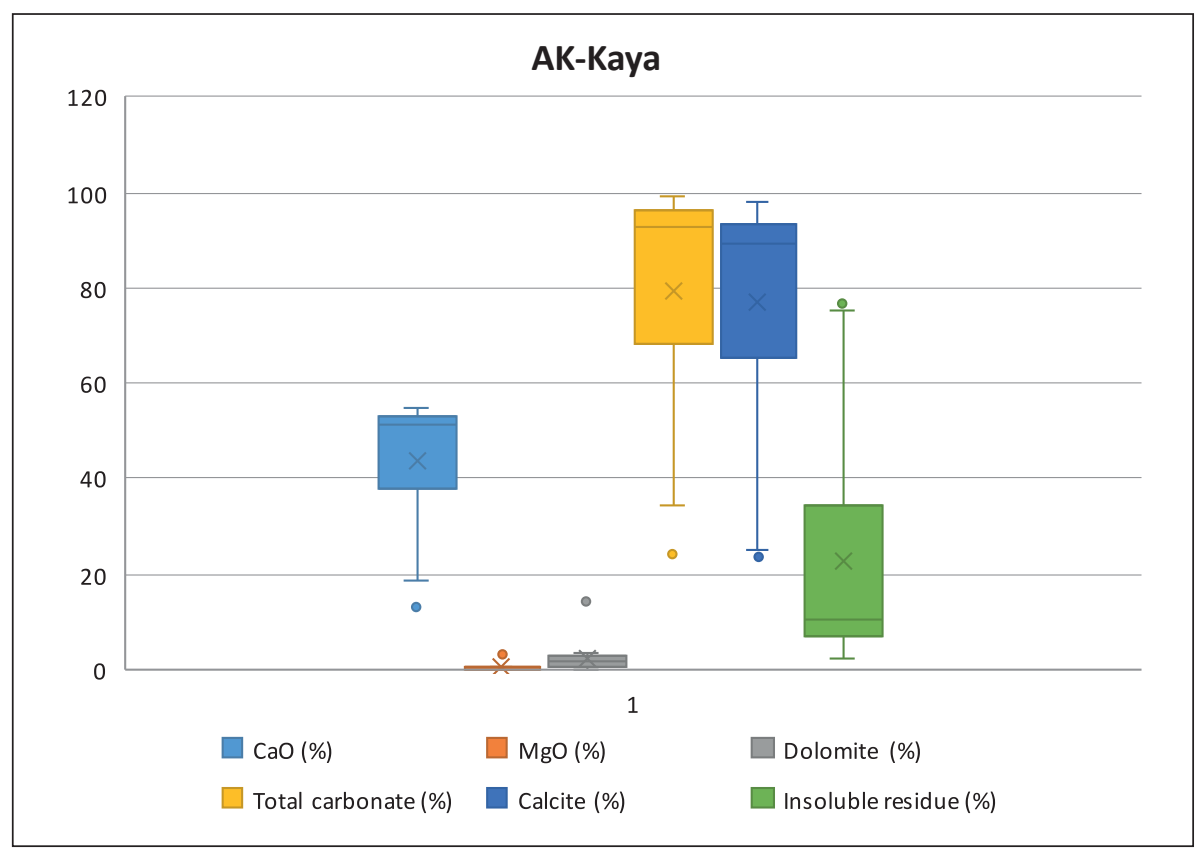

Fig. 7: Complexometric analyses, Ak-Kaya.

Tab. 1: Complexometric analyses of rock samples, Ak-Kaya.

\begin{tabular}{|c|c|c|c|c|c|c|c|}
\hline Rock sample & CaO (\%) & MgO (\%) & Dolomite (\%) & $\begin{array}{c}\text { Total } \\
\text { carbonate (\%) }\end{array}$ & Calcite (\%) & CaO/MgO & $\begin{array}{c}\text { Insoluble } \\
\text { residue (\%) }\end{array}$ \\
\hline AAD1 & 13.40 & 0.20 & 0.92 & 24.34 & 23.42 & 66.48 & 76.58 \\
\hline AAD2 & 53.16 & 0.77 & 3.50 & 96.49 & 92.99 & 69.40 & 7.01 \\
\hline AAD3 & 51.37 & 0.36 & 1.66 & 92.44 & 90.78 & 141.56 & 9.22 \\
\hline AAD4 & 47.56 & 0.12 & 0.55 & 85.13 & 84.58 & 393.15 & 15.42 \\
\hline AAD5 & 48.90 & 0.28 & 1.29 & 87.87 & 86.58 & 173.26 & 13.42 \\
\hline AAD6 & 50.08 & 3.10 & 14.20 & 95.88 & 81.67 & 16.13 & 18.33 \\
\hline AAD7 & 52.32 & 0.16 & 0.74 & 93.72 & 92.99 & 324.42 & 7.01 \\
\hline AAD8 & 47.61 & 0.60 & 2.77 & 86.24 & 83.48 & 78.72 & 16.52 \\
\hline AAD9 & 18.90 & 0.40 & 1.84 & 34.57 & 32.73 & 46.87 & 67.27 \\
\hline AAD10 & 28.26 & 0.44 & 2.03 & 51.37 & 49.35 & 63.73 & 50.65 \\
\hline AAD11 & 52.94 & 0.52 & 2.40 & 95.58 & 93.19 & 101.00 & 6.81 \\
\hline AAD12 & 52.49 & 0.40 & 1.84 & 94.53 & 92.68 & 130.19 & 7.32 \\
\hline AAD13 & 51.09 & 0.69 & 3.14 & 92.62 & 89.48 & 74.53 & 10.52 \\
\hline AAD14 & 14.02 & 0.08 & 0.37 & 25.19 & 24.82 & 173.86 & 75.18 \\
\hline AAD15 & 54.85 & 0.16 & 0.74 & 98.23 & 97.49 & 340.07 & 2.51 \\
\hline AAD16 & 54.79 & 0.60 & 2.77 & 99.05 & 96.29 & 90.59 & 3.71 \\
\hline AAD17 & 54.79 & 0.02 & 0.09 & 97.75 & 97.84 & 2717.77 & 2.16 \\
\hline
\end{tabular}


synchronization with the total carbonate content. There is a significant proportion of insoluble residue in the profile. In four samples the value of insoluble residue exceeds $50 \%$, and the average for all samples is almost $23 \%$.

\section{ROCK RELIEF OF ROCK PILLARS}

The tops of the rock pillars are dissected by characteristic rock relief. The wider overgrown pillars are dissected by subsoil rock forms, subsoil cups and channels (Fig. 4a; Fig. 8a in Appendix), and their denuded parts by rain flutes (Fig. 4b; Fig. 8b in Appendix). Rain flutes also dominate on pointed and narrower tops of oblong rock pillars (Fig. 8c in Appendix).

Unique but relatively characteristic for this type of rock base and conditions is the rock relief on the walls of the pillars, walls that formed in parallel with thin rock layers (Figs. 9a-c in Appendix). The layers' thickness is from several centimeters to several decimeters. On transverse walls and on walls where the layers overhang, traces of rock disintegration dominate. Subsoil rock forms also dominate on gently sloping, stepped sections of the walls (Fig. 4c; Figs. 9b-c in Appendix).

Rock pillars develop three-dimensionally. Water flows from the top and sides between surfaces of the cleavage fissures. Characteristic networks of smaller tubes occur (Fig. 10a in Appendix) surrounding the impermeable sections of the contact. The tubes are centimeters in diameter, often even smaller, and only rarely are one decimeter in diameter and thus wide and low. A vertical orientation of the tubes dominates (Figs. 10a-c in Appendix), and along poorly permeable contacts they are meandering in shape (Fig. 10d in Appendix). In the dense network of tubes, only protuberances remain (Figs. 10b-c in Appendix), the traces of the former edges of tubes. Due to the rock peeling off, the networks of tubes are denuded and reshaped by the water that creeps down the walls.

On overhanging, stepped sections, bell-like pits developed on the outlets of the tubes (Fig. 10e in Appendix; Slabe 1995, p. 83) and below them, smaller channels.

On both, gently sloping and steep sections of the walls, steps are found at the top of the layers of the rock (Fig. 4d; Fig. 11a in Appendix). They are individual or, on the gently sloping section of a wall, one above the other (Figs. 11b-c in Appendix). Different sections of the wall peel off more or less distinctly. The steps are bare and relatively flat or dissected, they can be several meters long, and some are dissected by pits (Fig. 4e; Fig. 11d in Appendix) that develop due to the water creeping along the wall or by subsoil rock forms with vegetation (Fig. 11e in Appendix).

The walls at the feet of the rock pillars are rounded and relatively smooth. Shallow funnel-like notches (Figs. 12a-c in Appendix) and shallow half-bells (Fig. 4f; Fig. 12d in Appendix; Slabe \& Liu 2009, p. 136) indent the gently sloping sections, and larger wall channels (Fig. 4g) that developed along vertical notches lead to them. On the walls, the subsoil rock forms are dominated by cups (Fig. 4a) measuring centimeters or decimeters in diameter. In most cases, they start to form beneath moss patches, which first cover the rock (Figs. 13a-c in Appendix). Water creeping down the walls, flowing cleavage fissures, also carries soil and deposits it. The largest cups (Fig. 13a in Appendix; Figs. 13d-e in Appendix), which measure decimeters in diameter, are covered with several centimeters of soil. They can be strung one beside another along an entire shelf (Fig. 13d in Appendix). Along cleavage fissures, they are often narrow and oblong. In places along the entire shelf that forms along cleavage fissures, a subsoil channel develops with one or more outlets at its lowest part with wall channels below them. Wall channels measuring centimeters or decimeters in diameter are found frequently beneath subsoil cups. The largest ones, several decimeters in diameter, are beneath large and overgrown steps (Fig. 4h; Figs. 14a-b in Appendix). On overhanging parts of the walls, there are half-bell forms. They are particularly pronounced at the end of inclined wall steps when most of the water flows from a channel on the shelf in a single place (Fig. 11a in Appendix; Fig. $11 \mathrm{c}$ in Appendix). Beneath shelves that are evenly covered by soil, run-off channels are found over the entire surface of the inclined wall. Pits are often found on their bottoms (Fig. 14b in Appendix). Channels also form due to water flowing from bare rock surfaces (Fig. 8c in Appendix; Figs. 11c-d in Appendix; Fig. 14c in Appendix). Most subsoil cups have round or elliptical cross-sections, and some have triangular cross-sections with a funnellike outlet (Fig. 13d in Appendix). This characteristic is often found in cups, whether in bare solution pans or in subsoil cups that form on gently inclined walls where water creeps over large surfaces or flows from them in distinct streams. Water that permeates through the soil also flows along cleavage fissures beneath it. Subsoil rock relief with vegetation therefore dominates on gently sloping stepped sections. Only rarely do subsoil wall cups occur. As a rule they are found above subsoil cups and measure decimeters in size. Water also flows into them along cleavage fissures above them. Smaller ceiling pockets (Fig. 4i; Fig. 10e in Appendix) form at the mouths of the inflows. Water reaching soil flows alongside it. On wider and less inclined wall shelves, networks of smaller subsoil flutes occur along which the water creeps downward across the entire surface (Fig. 14b in Appendix).

Pits develop from the dominant creeping of larger amounts of water down the vertical and gently sloping walls (Figs. 15a-d in Appendix). They are semi-spherical, 
some have flat bottoms, and their diameters reach a few centimeters in size. Inflow channels of equal diameters and up to ten centimeters in length lead into them. The pits are distributed across the rock relative to spots of weakness, in most cases individually (Fig. 15a in Appendix), but also one above the other, and in places adjacent and linked in a network (Fig. 15c in Appendix); on wall steps they are arranged as a rule in transverse rows. Several can merge in a funnel-like notch. They can also develop in the channels that lead from wall steps. In places, they transit one into another in a cascade (Fig. 11b in Appendix). In the long-term development of a network of pits, protuberances that were the edges of pits can dominate the rock relief, mainly on the more gently sloping sections of walls (Fig. 11d in Appendix; Fig. 14c in Appendix). Are these pits of biocorrosion origin, formed beneath small surfaces of moss (Fig. 15d in Appendix)? Water that creeps down the wall deposits soil on their bottoms. Occasionally, they also form like subsoil cups or solution pans.

On the most gently sloping and stepped parts of the wall where subsoil forms are most numerous and largest, they contain vegetation, and the rock is the most distinctly covered in lichen and mosses.

Protuberances are found between larger channels that meander from the subsoil rock forms (Fig. 14a in Appendix). They are either individual or joined in clusters and are pointed, reaching 20 centimeters in height. Protuberances between transformed channels that developed along cleavage fissures have similar shapes, but are much smaller, only a few centimeters in size (Fig. 10c in Appendix). The larger channels deepen at a faster rate due to the water that trickles on the gently sloping surface where they are found.

Scallops are found on individual sections of overhanging walls and develop due to the water creeping over large surfaces of the rock.

Rain flutes form on the parts of the rock that protrude from the walls and are directly exposed to rain, are not completely covered with distinct lichen and moss, and where the water that trickles down from higher up is not abundant (Fig. 8c in Appendix). The rock relief on such surfaces is often composite, with distinct elements of rain flutes and pits as well as possibly subsoil cups and channels leading from them. On overhanging parts, scallops (Fig. 4j) gradually form, the trace of steady creeping water.

Large parts of the walls are overgrown with lichen and moss. The rock beneath them is relatively smooth and rounded.

\section{LITHOLOGICAL CHARACTERISTICS AND ROCK RELIEF OF KARREN IN AK-BOM IN THE CHUYA VALLEY}

\section{SHAPE OF PILLARS}

Ak-Bom is one of the largest and best known karst areas in the Altai Republic (Fig. 1; Fig. 16). Karst with all the characteristic phenomena developed in a few hundred meters wide and almost 200 meters high belt of carbonate rock on both sides of the Chuya River. One
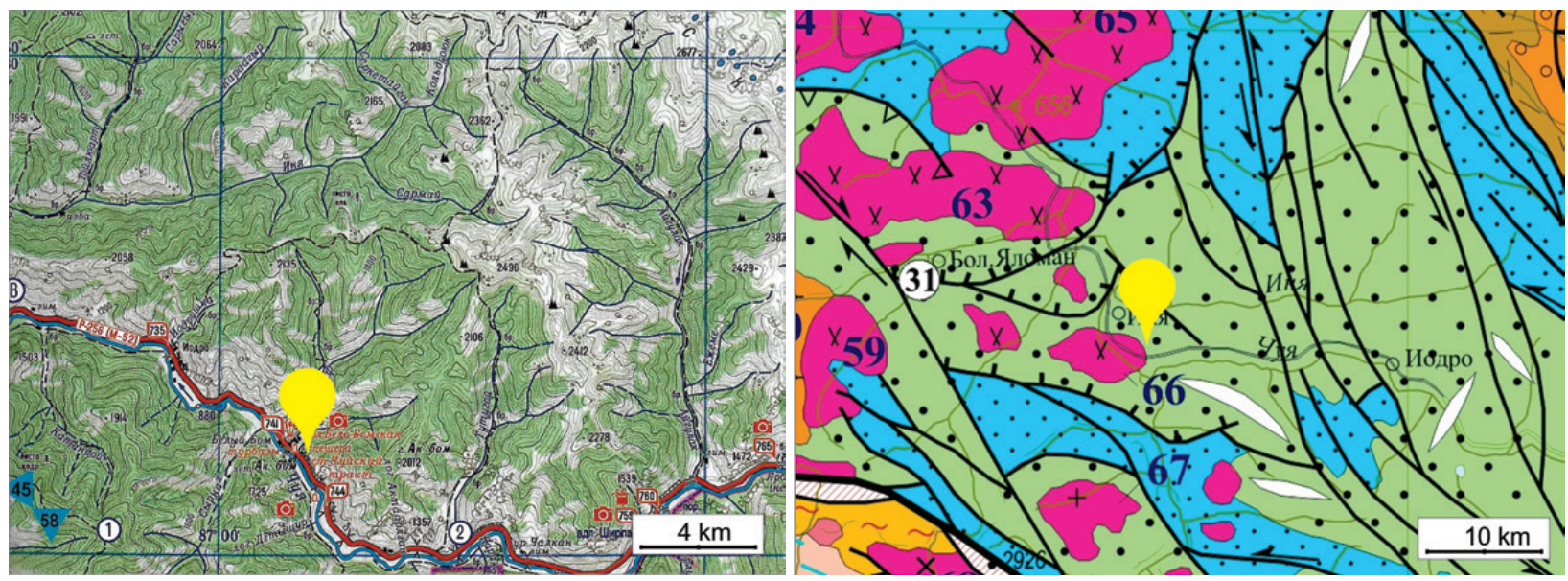

Fig. 16: Left: topographic map (Valiy \& Strebkov 2018) of the research point at Ak-Bom. Right: geological map (Turkin et al. 2004) of the research point at Ak-Bom, carbonates in green color. 
of its largest caves is open to a wide variety of visitors. Part of the rock, particularly the steep slopes of the valley, is denuded and offers an insight into the development and shaping of the karren (Figs. 17-18). The steep slope is composed of many steps with shelves and intervening steep belts, including walls of noncarbonate rock. Their formation in the lower and middle part of the slope is described in detail. The rock masses are rounded, especially the lower parts.

The Chuya Valley bottom sides and in places the high floors of side valleys as well are filled with fluvial sediment (Figs. 19a-b in Appendix; Figs. 19-20 in Appendix; Figs. 22-26 in Appendix). The rims of the valleys are therefore also widened by erosion.
The rock relief formed beneath the sediment and soil testifies of the karst development and reveals the characteristic formation of denuded rock.

\section{GEOLOGY}

The investigated samples belong petrographically among calcite marbles with variable content of silicate admixtures, altered in the lower greenschist facies conditions. According to the Munsell Rock-Color Chart (2009), they are predominantly white (N9) and grey in color, varying from N5 to N8. Some have a slightly pinkish tint (5 YR 8/1) and contain grey fields (N5 do N7) that are irregularly shaped or banded. On the macroscopic scale, oriented and less often schistose structures are pronounced,
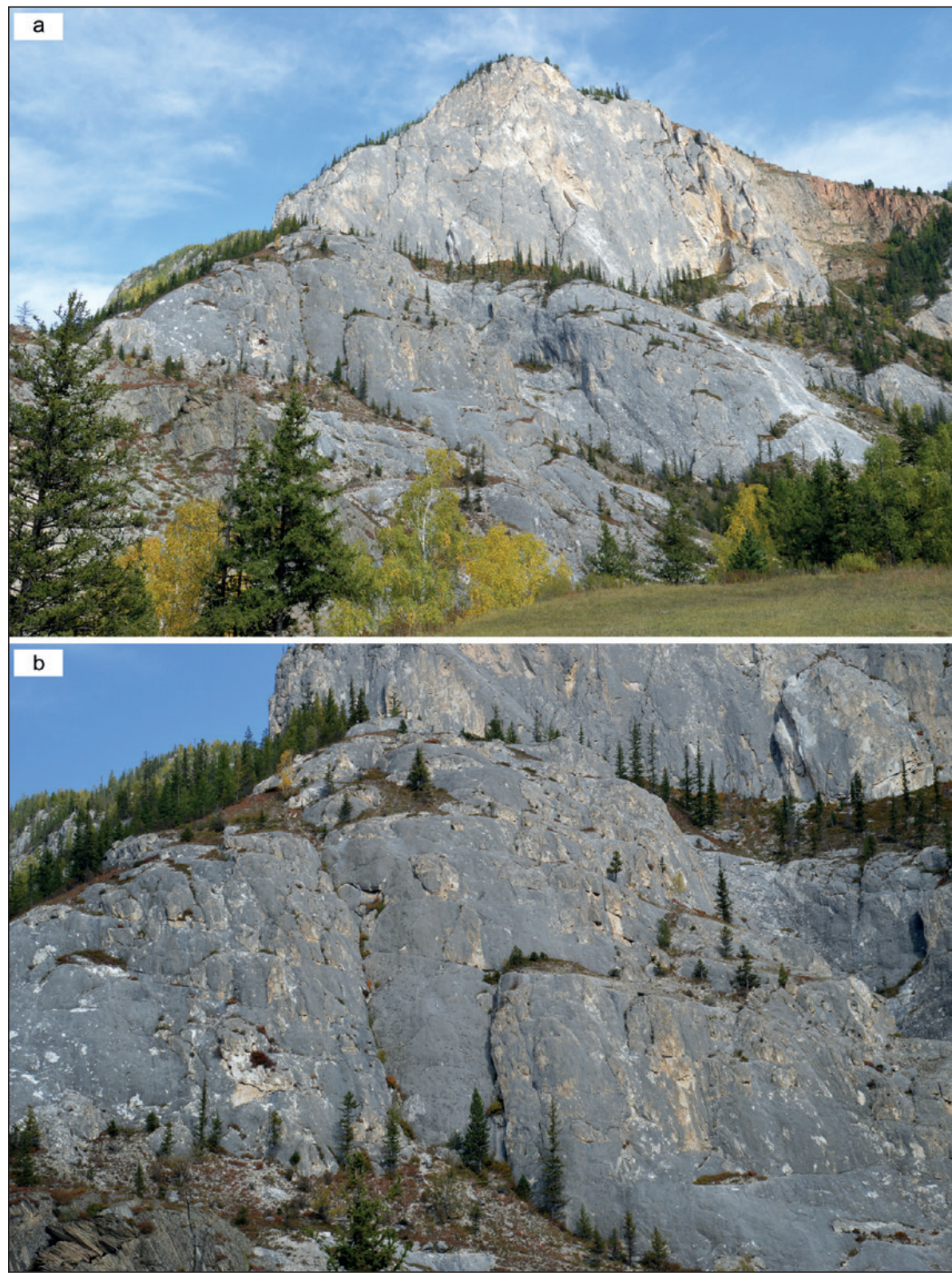

Fig. 17: Ak-Bom: a. denuded rock surface of karren in the Chuya Valley above Ak-Bom, b. unique formation with peeling off due to high temperature oscillation (Photo: $M$. Knez). 


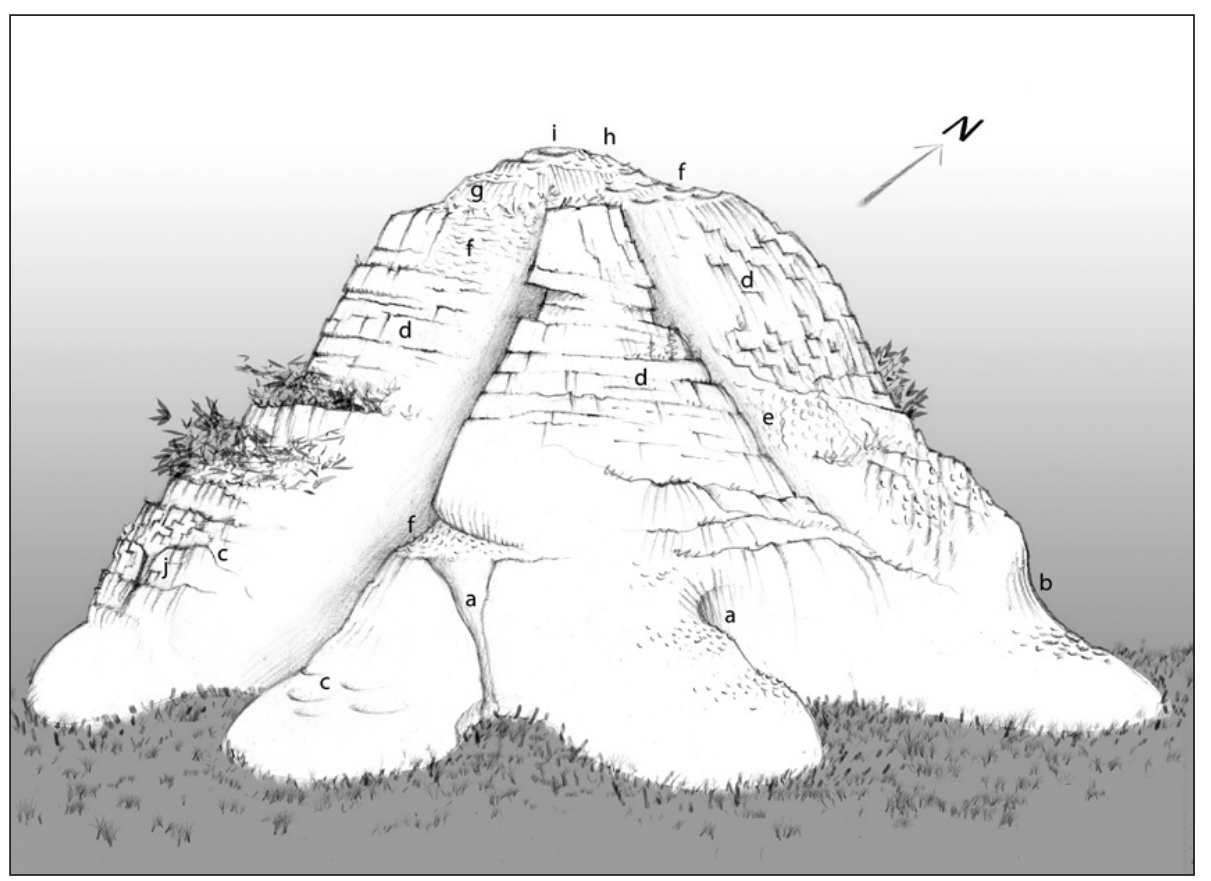

Fig. 18: Karren on marble, AkBom: a. funnel-like notch, $b$. subsoil notch, c. subsoils cups, d. steps, e. pits, f. cups, g. rain flutes, $h$. rain pits, $i$. solution pan, $j$. wall channel. A rock wall is $20 \mathrm{~m}$ high.

forming slightly anastomosing cleavage along shear deformations (Figs. 20a-b in Appendix). In compressional conditions, individual greyish or brownish colored stylolites formed. Some of the samples are heavily cracked. The deformation appears as partly or non-mineralized fractures and fissures. In such cases the rock is hygroscopic and subject to intense disintegration. It reacts very strongly with diluted $\mathrm{HCl}$ (1:10 ratio), indicating large specific surface.

The marbles originate mostly from relatively pure limestone with calcite veins, subordinately from cherty limestone (Fig. 20c in Appendix) and occasionally from limestone with laminae and layers of sericite quartz siltstone (Figs. 20d-e in Appendix). Clayey admixtures in the parent limestone recrystallized into white mica (muscovite) and chlorite ( \pm albite). The mineral association belongs to a low degree of regional metamorphism in the greenschist facies. Petrographic analyses indicate polyphase deformations. Dynamometamorphic shear deformations followed marmorization. As a consequence, the strained mineral grains have lenticular shape (Fig. $20 \mathrm{f}$ in Appendix). Foliation developed and laminas are completely disintegrated together with veins, and chert nodules, which are usually mixed with the marble in a shear zone (Fig. 20g in Appendix). Recrystallized clayey material forms passively concentrated chlorite and sericite pockets (Fig. 20h in Appendix) and coatings smeared on the cleavage surfaces. Due to the differences in hardness and resistance to weathering, channeled surfaces form locally (Figs. 20a-b in Appendix). The pronounced heterogeneity of the calcite grains size is a consequence of an uneven degradation of the marble. This especially holds for numerous coarse-grained veins in it (Fig. 20i in Appendix), and some fossil fragments that are similar to corals (Fig. 20j in Appendix), molluscs, crinoids, etc. (Fig. 20k in Appendix).

The marbles are composed on average of over $95 \%$ calcite. Their texture is mostly heteroblastic, formed in the dynamometamorphic conditions under direct stress after progressive recrystallization of the parent limestone. The calcite grains are therefore degradationally recrystallized, most frequently even mylonitized (Fig. 201 in Appendix). The remaining calcite porphyroclasts have numerous deformational lamellas with subgrains in and at the margins of the grains. The latter are often surround by micro-fractures. In the late stage of dynamic deformation, secondary chlorite (Fig. 20m in Appendix), sericite, calcite, and quartz grew in the less strained parts of the rock or in pressure shadows (Fig. 20e in Appendix). Along some fractures, stylolites originated locally. In the shear-deformed silty layers, the rock has a distinct foliation marked by the preferred orientation of white mica and chlorite (Fig. 20e in Appendix). Opened fractures are most common in the direction of foliation (Fig. 201 in Appendix; Fig. 20n in Appendix). This is at the same time the direction of preferential cleaving and peeling of the rock. The above characteristics make the rock unstable and sensitive for mechanical and temperature damage.

\section{COMPLEXOMETRIC TITRATION ANALYSES}

Sixteen complexometric titration analyses were performed on 16 rock samples (Tab. 2; Fig. 21). All the sam- 
ples from the profile exceed $85 \%$ total carbonate, but there are just two samples between $85 \%$ and $95 \%$. Two samples contain between $95 \%$ and $98 \%$ total carbonate, four between $99 \%$ and $100 \%$, and eight are pure carbonate with $100 \%$ total carbonate. The average value of all samples is almost $98 \%$. All of the samples show a high percentage of calcite. Only four samples were less than $95 \%$ calcite, and the average value of all samples is over $96 \%$. All of the samples also contain a significant proportion of dolomite. Five samples have less than $2 \%$ dolomite, three between $1 \%$ and $2 \%$, three between $2 \%$ and
$3 \%$, seven between $3 \%$ and $6 \%$, and one between $6 \%$ and $7 \%$. The average value totals $2.9 \%$. Insoluble residue in the profile shows a smaller proportion. In three samples the value of insoluble residue is below $1 \%$, in eight samples below 3\%, in two samples between $15 \%$ and $18 \%$, and the average for samples (omitting the two between $15 \%$ and $18 \%$ ) is less than $2.2 \%$.

\section{ROCK RELIEF OF ROCK PILLARS}

At the contact with alluvial sediment, the rock as a rule is characteristically subsoil formed. The sediment ranges

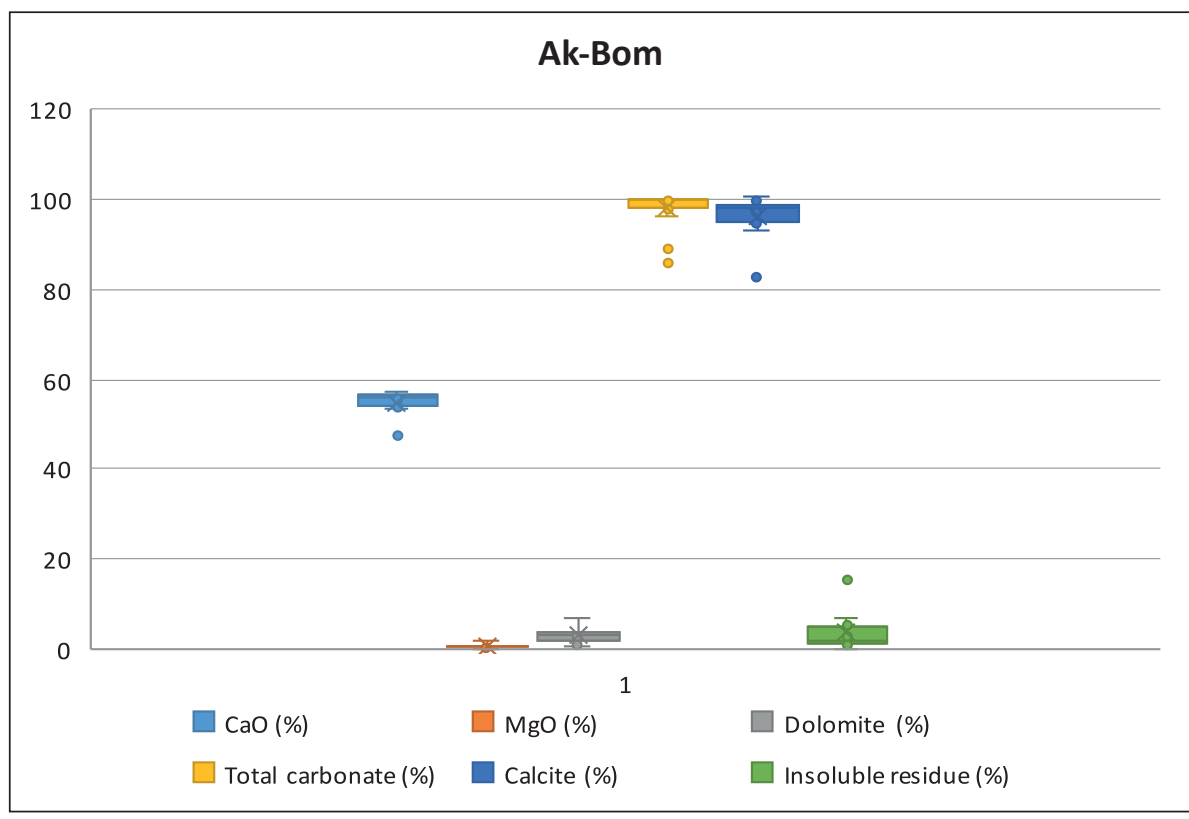

Fig. 21: Complexometric analyses, Ak-Bom.

Tab. 2: Complexometric analyses of rock samples, Ak-Bom.

\begin{tabular}{|c|c|c|c|c|c|c|c|}
\hline Rock sample & $\mathrm{CaO}(\%)$ & $\mathrm{MgO}(\%)$ & Dolomite (\%) & $\begin{array}{c}\text { Total } \\
\text { carbonate (\%) }\end{array}$ & Calcite (\%) & CaO/MgO & $\begin{array}{c}\text { Insoluble } \\
\text { residue (\%) }\end{array}$ \\
\hline A1 & 56.75 & 0.73 & 3.32 & 100.00 & 99.49 & 78.20 & 0.51 \\
\hline A2 & 55.86 & 0.08 & 0.37 & 99.86 & 99.49 & 692.65 & 0.51 \\
\hline A3 & 47.28 & 0.65 & 2.95 & 85.73 & 82.78 & 73.28 & 17.22 \\
\hline A4 & 55.91 & 0.48 & 2.21 & 100.00 & 98.59 & 115.56 & 1.41 \\
\hline A5 & 55.58 & 0.52 & 2.40 & 100.00 & 97.89 & 106.03 & 2.11 \\
\hline A6 & 56.64 & 1.45 & 6.64 & 100.00 & 97.49 & 39.02 & 2.51 \\
\hline A7 & 56.02 & 0.81 & 3.69 & 100.00 & 97.99 & 69.47 & 2.01 \\
\hline A8 & 56.53 & 0.81 & 3.69 & 100.00 & 98.89 & 70.10 & 1.11 \\
\hline A9 & 57.09 & 0.40 & 1.84 & 100.00 & 100.89 & 141.59 & 0.00 \\
\hline A10 & 55.52 & 0.32 & 1.48 & 99.77 & 98.29 & 172.12 & 1.71 \\
\hline A11 & 53.50 & 0.24 & 1.11 & 95.99 & 94.89 & 221.15 & 5.11 \\
\hline A12 & 55.74 & 0.20 & 0.92 & 99.91 & 98.99 & 276.51 & 1.01 \\
\hline A13 & 48.68 & 0.97 & 4.43 & 88.90 & 84.48 & 50.30 & 15.52 \\
\hline A14 & 54.62 & 0.73 & 3.32 & 99.01 & 95.69 & 75.26 & 4.31 \\
\hline A15 & 56.53 & 0.81 & 3.69 & 100.00 & 98.89 & 70.10 & 1.11 \\
\hline A16 & 53.50 & 1.05 & 4.79 & 97.68 & 92.89 & 51.03 & 7.11 \\
\hline
\end{tabular}


from large pebbles all the way down to tiny-grained pieces. At the contact with the latter in particular, the characteristic subsoil rock relief develops. The rock is relatively smooth and rounded (Fig. 22a in Appendix) and is dissected by characteristic subsoil forms.

Beneath the beginning of the contact, there are funnel-like notches (Fig. 18a; Figs. 22b-c in Appendix), and below them are large and mostly shallow (up to one meter wide and several tens of centimeters deep) water channels. In places of evenly creeping sheets of water along the contact, there are large subsoil scallops (Fig. 22d in Appendix). At the long-term levels of the cover there are subsoil notches (Fig. 18b; Fig. 22e in Appendix).

Subsoil cups (Fig. 18c; Fig. 22f in Appendix) are found on the more gently sloping parts of mostly denuded rock beneath places that are covered by sediment, which is either original or has been deposited downward on the walls. Even the larger stairs (up to one meter wide) that dissect the walls have this type of formation (Fig. 22g in Appendix). Often, the original shelves that are a consequence of the rock peeling off, and the gently sloping parts, became covered by sediment, and in places by vegetation as well (Fig. $22 \mathrm{~h}$ in Appendix). The surface beneath the sandy slope gravel is smooth since it also disintegrates into tiny particles.

Gradually, the uncovered subsoil surface is transformed (Fig. 23a in Appendix). Sheets of creeping water carve steps (Fig. 18d; Figs. 23b-c in Appendix). They reflect the trace of the rock peeling off and are therefore formed on the lower part of the rockfall. They can be a decimeter or more in length, and usually only a few centimeters in width, rarely a decimeter, which depends also on the size of the rock plate or rockfall. In places they cascade one below the other, which testifies to a local pronounced stream. Many are dissected by pits (Fig. 18e) measuring a few centimeters in diameter that can be strung longitudinally and are a composite form (see below). On inclined steps they are arranged in cascades one above the other to the side edge or they run funnel-like to an outlet for the water in the middle.

The cups (Fig. 18f; Figs. 24a-b in Appendix) with diameters between 5 and $10 \mathrm{~cm}$ appear to originate due to biocorrosion and partly to subsoil transformation that have been reshaped by rainwater. They are found on both gently sloping and more inclined surfaces that were, and frequently still are, found in places covered by moss and lichen. They are dissected by smaller pits. On the more gently sloping parts their bottoms are dissected, and on more inclined surfaces their lower edges are dissected by pits. Sediment carried by trickling water is often found in them so that even the pits dissecting the lower parts seem to be of subsoil and sub-vegetation origin. As a rule, they are found on sunless surfaces. The water transforms the denuded cups like solution pans. Their subsoil origin is also indicated by the surfaces between them that are dissected by rain flutes, which have been denuded for some time.

Rounded and inclined but not steep surfaces of the rock on which water flows are dissected by belts of pits ( 1 to $2 \mathrm{~cm}$ in diameter). They also dissect the surface of steps (Figs. 24c-d in Appendix). They seem to be the trace of a combination of factors: biocorrosion, subsoil processes, direct rain, and trickling water. Water is important for the accelerated growth of the mosses and lichens that as a rule cover their bottoms. The more gently sloping sections are dissected more distinctly, as is the surface of steps where there is a gradual transition from a smooth subsoil surface to a surface dissected by pits. Often, the pits in whose development subsoil and biocorrosion factors have an important impact are widened in the lower part (Fig. 24d in Appendix). They are found on larger rock shelves or steps. Where direct rain dominates, they are usually open (Fig. 24b in Appendix).

Rain flutes (Fig. 18g; Figs. 25a-c in Appendix) found on the surface of the rock that has been denuded for a longer period and gradually dissected can also be cuplike in shape. On gently sloping surfaces they occur on ridges protruding from the rock. They also dissect steep walls of steps with, of course, water trickling down the wall.

There are rain scallops on steep and overhanging surfaces where rainwater or water from the sediment flows (Fig. 25d in Appendix).

On horizontal and gently sloping denuded surfaces, there are rain pits (Fig. 18h; Fig. 22e in Appendix; Figs. 25c-d in Appendix; Figs. 25f-g in Appendix) that are often a composite rock form (Fig. 25c in Appendix), as described previously. When rain is the dominant factor, they are more open and occur side by side. Gradually, they cover denuded surfaces (Fig. 25h in Appendix).

Solution pans (Fig. 18i; Fig. 25i in Appendix), another composite rock form, appear on wall steps. They are carved by water trickling down the walls and direct rain drops. They also form biocorrosion cups (Figs. 25j-k in Appendix) and their bottoms are often dissected by pits.

Channels form due to a concentrated flow of water. They are found on surfaces dissected by cups where rainwater collects (Fig. 18j; Fig. 25k in Appendix). The channels, which are individual or linked in branched networks and often contain cups (Fig. 251 in Appendix), form on surfaces where water flows from the covering 
of soil or sediment composed of particles of broken rock and vegetation on the top of the wall, shelf, or subsoil cup. Large wall channels as a rule are found under tree growth (Fig. 25m in Appendix), and small ones beneath sediment covered with grass.

In large measure, peeling is dominant for the formation of bare rock. The plates, which are relatively thin, are of different sizes and their surfaces measure from a few square centimeters to many square meters (Figs. 26a-e in Appendix). Larger plates also break into smaller parts (Fig. 26f in Appendix). Steep and gently sloping walls alike display peeling off. It can dominate completely (Fig. $26 \mathrm{~g}$ in Appendix), intertwine with other factors (Fig. 26h in Appendix), or on its basis other factors can dominate (description of peeled off plates above). Often, however, the development of rock plates alternates with other rock forms. Traces of the latter (pits, for example; Figs. 26i-j in Appendix) can fall away.

The surfaces are often stepped, and the steps vary in size (see above). Rainwater and creeping water can transform surfaces where peeling off has put its fundamental stamp. As a rule, sunny and denuded surfaces display peeling off. This is also indicated on tops that are dissected by cups on the sunless sides while parts on the sunny sides that have been denuded for a long time are shaped by continuous peeling off, which is not least evident as well in the surface, a lighter color of the rock (Figs. 26g-h in Appendix), and the smooth subsoil, recently denuded surface; covered rock does not display peeling. Peeling puts its own stamp also in the uniform roundedness of walls (Figs. 261-m in Appendix). Peeling off is the most distinct in parts of the rock that protrude from the wall (Fig. 26i in Appendix). Gravel often accumulates on the steps and the rock beneath it is transformed (Fig. $25 \mathrm{j} \mathrm{in}$ Appendix). Surfaces exposed to sun rays at a greater angle disintegrate more distinctly while rain forms dominate on flat tops above them (Fig. 25c in Appendix).

Peeling off of the sunny rock surfaces (Ollier 1984, p. 15, p. 18), is the consequence of the impact of temperature changes on the intergranularly porous and moist rock. Convex parts and parts exposed perpendicularly to sun rays disintegrate the most distinctly, the rock flattens, and the walls become rounded.

\section{LITHOLOGICAL CHARACTERISTICS AND ROCK RELIEF OF KARREN AT THE CONFLUENCE OF THE CHUYA AND KATUN RIVERS}

\section{SHAPE OF ROCK PILLARS}

The southwestern slope of the mountain above the confluence of the Chuya and Katun rivers (Fig. 1; Fig. 27) is rocky. It is steep in the upper part and relatively gently sloping, and recently denuded from alluvial sediment, in the lower part (Figs. 28a-b). The largest part of the rock of the latter area is relatively rounded and smooth (Fig. 28c); disintegrated and peeled off parts put a distinctive stamp on it (Fig. 28d; Fig. 29).
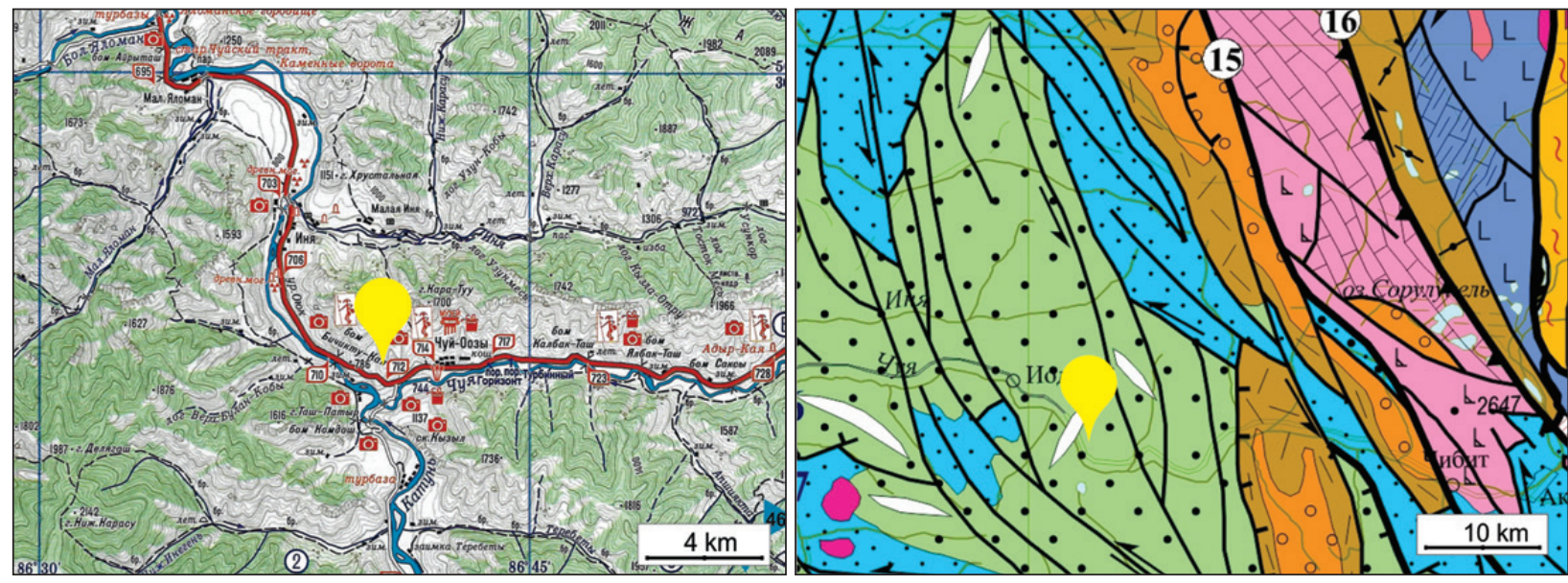

Fig. 27: Left: topographic map (Valiy \& Strebkov 2018) of the research point at the confluence of the Chuya and Katun Rivers. Right: geological map (Turkin et al. 2004) of the research point at the confluence of the Chuya and Katun Rivers, carbonates in green color. 

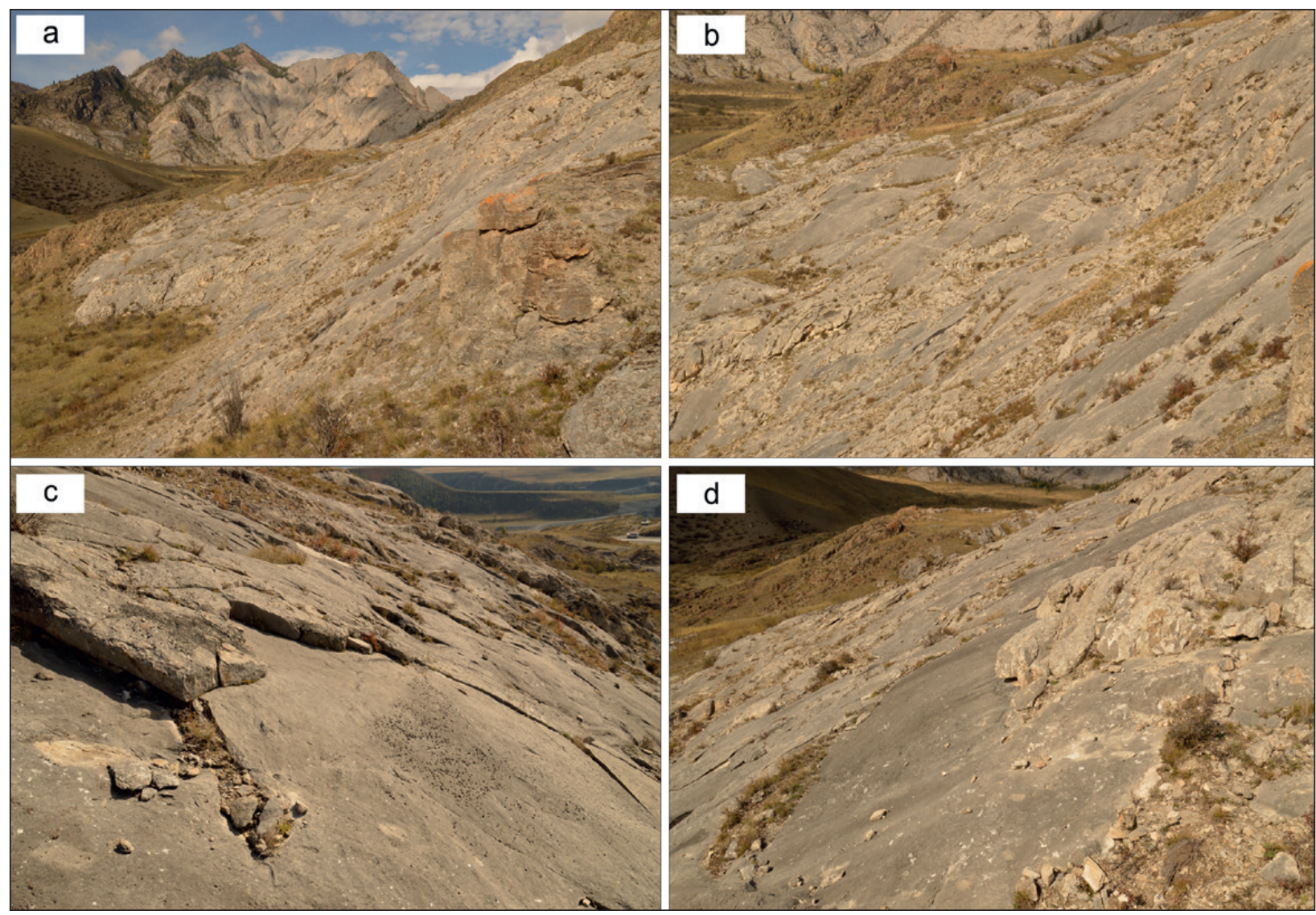

Fig. 28: Southwestern slope at the confluence of the Chuya and Katun Rivers: $a$, b. gently sloping and denuded surface, c. part of rounded and smooth rock, $d$. parts of rock that disintegrated and peeled off (Photo: M. Knez).

\section{GEOLOGY}

In terms of composition and textural characteristics, marbles from the confluence of the Chuya and Katun rivers are comparable to the marble from the Ak-Bom area but they often have a coarser grained (saccharoid) structure. The collected samples show that they are more weathered than at the latter location. The color is also light grey, N6 to N8 (Munsell Rock-Color Chart 2009). The samples easily disintegrate into separate grains, and are highly hygroscopic. The reaction with diluted (1:10) $\mathrm{HCl}$ acid is strong. Some of the marbles have corroded superficial flowstone coatings.

Microscopically, investigated samples show no presence of silicate laminas, and therefore they have significantly less silicate minerals in the composition. They are composed mainly of coarse ( 0.5 to $2.3 \mathrm{~mm}$ ) calcite grains with numerous deformational lamellae and with subgrains in some cases (Fig. 30a in Appendix; Fig. 30 in Appendix; Figs. 32-35 in Appendix). Contacts between the grains are loose, and micro-fractures form an interconnected intergranular micro-porosity (Fig. 30b in Appendix) that makes the rock very hygroscopic. In some parts corrosion is noticeable between the grains and therefore they have jagged stylolitic contacts. This phenomenon is even more pronounced where opened corrosion pores were subsequently filled with calcite (Fig. 30c in Appendix). In addition to containing about $90 \%$ to $98 \%$ calcite, the mineral paragenesis includes also quartz ( \pm albite), a tremolite-actinolite type of amphibole with embryos of epidote (Fig. 30d in Appendix), white mica (muscovite), and secondary opaque minerals in micro-fractures and stylolites. The composition indicates recrystallization of clayey admixtures in the primary limestone and later metamorphism in the upper part of the greenschist facies. The protolith in all cases was more or less pure limestone, locally containing chert.

An interesting phenomenon is observed in sample C4 (16-D81) (Tab. 3). It has surficial calcite incrustation that contains tiny intensively yellowish-green inclusions of undetermined mineral similar to autunite $\left(\mathrm{Ca}\left(\mathrm{UO}_{2}\right)_{2}(\mathrm{PO} 4)_{2} \bullet 10-12\left(\mathrm{H}_{2} \mathrm{O}\right)\right.$. The calcite grains below this crust contain numerous linear tracks (fission tracks) (Fig. 30e in Appendix) that disappear toward the sample's interior, pointing to a strongly radioactive mineral.

Genetically unrelated to the marbles is sample C5 (16-D82) (Tab. 3). It was taken from a thin dike crosscut- 


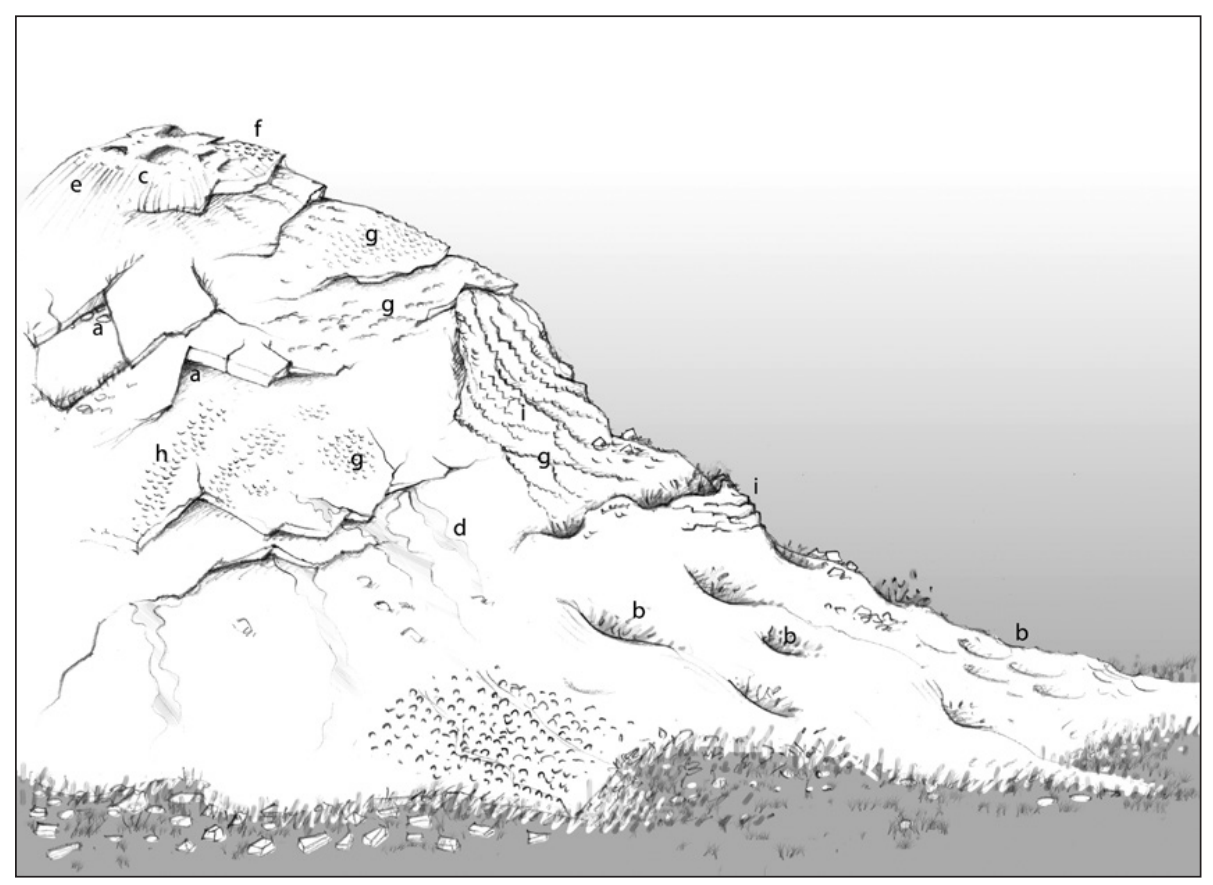

Fig. 29: Karren on marble, at the confluence of the Chuya and Katun Rivers: a. hollow below rock plates, b. subsoil cup, c. solution pan, $d$. channels, e. rain flutes, f. rain pits, g. pits, h. channels with cups, $i$. steps. A hill is $50 \mathrm{~m}$ high.

ting the marble (Fig. 30f in Appendix). The rock has porphyritic texture and olive grey color (5 Y 4/1). It belongs to altered basalt with an intersertal texture. Phenocrysts belonging mostly to pyroxene and subordinately to olivine are set in a groundmass of plagioclase laths and chlorite (Fig. 30g in Appendix). The products of alteration (saussuritization) are chlorite, epidote and some calcite, and traces of fibrous amphibole. Secondary quartz fills sparse micro-fractures.

\section{COMPLEXOMETRIC TITRATION ANALYSES}

Sixteen complexometric titration analyses were performed on 16 rock samples (Tab. 3; Fig. 31). We established (C5 excluded) that 12 samples reached $100 \%$ total

Tab. 3: Complexometric analyses of rock samples, the confluence of the Chuya and Katun rivers.

\begin{tabular}{|c|c|c|c|c|c|c|c|}
\hline Rock sample & CaO (\%) & MgO (\%) & Dolomite (\%) & $\begin{array}{c}\text { Total } \\
\text { carbonate (\%) }\end{array}$ & Calcite (\%) & CaO/MgO & $\begin{array}{c}\text { Insoluble } \\
\text { residue (\%) }\end{array}$ \\
\hline C1 & 55.13 & 0.89 & 4.06 & 100.00 & 96.19 & 62.15 & 3.81 \\
\hline C2 & 56.36 & 0.85 & 3.87 & 100.00 & 98.49 & 66.56 & 1.51 \\
\hline C3 & 56.08 & 0.89 & 4.06 & 100.00 & 97.89 & 63.22 & 2.11 \\
\hline C4 & 55.29 & 1.01 & 4.61 & 100.00 & 96.19 & 54.86 & 3.81 \\
\hline C5 & 2.52 & 3.75 & 12.35 & 17.15 & 4.80 & 0.67 & 95.20 \\
\hline C6 & 55.52 & 0.93 & 4.24 & 100.00 & 96.79 & 59.87 & 3.21 \\
\hline C7 & 54.85 & 0.97 & 4.43 & 99.91 & 95.49 & 56.68 & 4.51 \\
\hline C8 & 53.11 & 0.52 & 2.40 & 95.88 & 93.49 & 101.32 & 6.51 \\
\hline C9 & 56.02 & 0.24 & 1.11 & 100.00 & 99.39 & 231.58 & 0.61 \\
\hline C10 & 56.42 & 1.21 & 5.53 & 100.00 & 97.69 & 46.64 & 2.31 \\
\hline C11 & 57.03 & 0.48 & 2.21 & 100.00 & 100.59 & 117.88 & 0.00 \\
\hline C12 & 56.70 & 0.65 & 2.95 & 100.00 & 99.59 & 87.89 & 0.41 \\
\hline C13 & 55.91 & 0.85 & 3.87 & 100.00 & 97.69 & 66.03 & 2.31 \\
\hline C14 & 56.75 & 0.89 & 4.06 & 100.00 & 99.09 & 63.98 & 0.91 \\
\hline C15 & 56.47 & 0.52 & 2.40 & 100.00 & 99.49 & 107.74 & 0.51 \\
\hline C16 & 55.69 & 0.12 & 0.55 & 99.64 & 99.09 & 460.38 & 0.91 \\
\hline
\end{tabular}




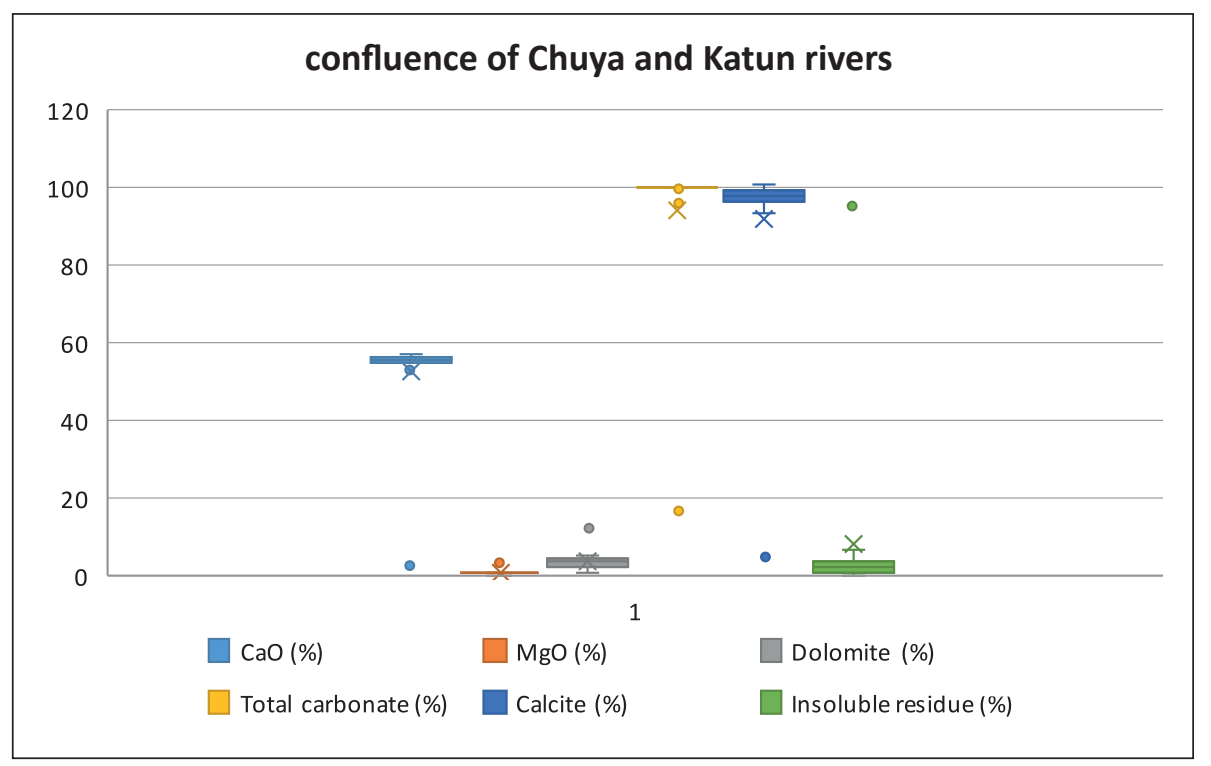

Fig. 31: Complexometric analyses, the confluence of the Chuya and Katun Rivers.

carbonate, two over 99\%, and one almost $96 \%$. The average value of all carbonate samples is almost $99.7 \%$. All of the samples show a high percentage of calcite. Only one sample had less than $95 \%$ calcite, only four samples less than $97 \%$, and the average value of the samples is over $98 \%$. All of the samples also contain a significant proportion of dolomite. One sample has less than $1 \%$ dolomite, one between $1 \%$ and $2 \%$, four between $2 \%$ and $3 \%$, two between $3 \%$ and $4 \%$, six between $4 \%$ and $5 \%$, and one over $5 \%$. The average value is $3.4 \%$.

Insoluble residue in the profile is similar to the two previous profiles. In six samples the value of insoluble residue is below $1 \%$, in four samples below $3 \%$, in two samples between $4 \%$ and $7 \%$, and the average is $2.2 \%$.

\section{ROCK RELIEF OF ROCK PILLARS}

Plates cover several square meters of surface (Figs. 32a$\mathrm{b}$ in Appendix). They developed along fissures following cleavage surfaces. Before a layer of rock below a plate splits off, a small hollow frequently forms along cleavage fissures and becomes filled with deposited gravel (Fig. 29a; Figs. 32 c-d in Appendix). When damp in winter, it freezes at low temperatures. The plate above the hollow protrudes, fractures (Figs. 32e-g in Appendix), and slides downwards in pieces (Fig. $32 \mathrm{~h}$ in Appendix). In places, the broken surface of the rock dominates and covers the rock (Fig. 32i in Appendix), particularly where noncarbonate layers of rock are also found. The ceilings of hollows are often covered with a layer of flowstone deposited above the sediment that fills the hollow (Figs. $32 \mathrm{j}-\mathrm{k}$ in Appendix).

A part of the surface is covered by rocky gravel, the remains of disintegration. Beneath the rubble and soil, the rock is subsoil smooth. Beneath river sediment and on the more gently sloping sections, subsoil cups are found beneath the accumulated rubble in most cases (Fig. 29b; Figs. 33a-b in Appendix). Solution pans form the denuded subsoil cups (Fig. 29c; Fig. 33c in Appendix). Moist areas are shaped by biocorrosion beneath moss (Fig. 33d in Appendix).

Channels a few centimeters in size lying side by side, lead from the subsoil surfaces (Fig. 34a in Appendix). Water also discharges along cleavage fissures and interlayer hollows (Fig. 29d; Figs. 34b-d in Appendix). Channels also occur on the walls of steeper sections between gently sloping surfaces of the rock (Fig. 34e in Appendix).

Rain flutes are found on the edges that have been denuded for a longer period (Fig. 29e; Figs. 34f-i in Appendix), and rain pits on gently sloping surfaces (Fig. 29f; Fig. 34j in Appendix). Water from them collects in channels (Fig. 34k in Appendix).

Parts of the relatively slightly rounded and smooth surfaces, where water flows down larger surfaces, are dissected by pits (Fig. 29g; Fig. 35a in Appendix). The pits a few centimeters in size, representing a composite between rain pits and initial solution pans (Fig. 35b in Appendix), biocorrosion pits (Fig. 35c in Appendix), and subsoil pits (Fig. 35d in Appendix). They are often asymmetric, shallower on the inflow side and deeper on the runoff side, and often connected in transverse strings (Figs. 35e-g in Appendix), especially on the steps where they are usually larger (Fig. 35h in Appendix). The bottoms that are covered with moss or sediment are often dissected by smaller pits (Fig. 35i in Appendix), while the bottoms of those along which water flows more distinctly are smooth (Fig. 35j in Appendix). They are similar to those in Ak-Bom. They are not found, of course, on freshly exposed surfaces beneath peeled off plates 
(Fig. 35k in Appendix). Meandering channels are carved more deeply. In places, there is a combination of both rock forms (Fig. 29h; Fig. 351 in Appendix), a surface of pits with channels in between. The channels can be pit- ted. Beneath sheet flow that transforms the traces of thin scaly rock, gently sloping parts of the rock are dissected into steps (Fig. 29i; Fig. 35h in Appendix; Fig. 35m in Appendix). Pits develop on them later.

\section{CONCLUSION}

An examination of the microscopic properties of the investigated rocks reveals the main causes for the pattern of their karstification and disintegration.

Lithologically, the rocks belong to pure and silicate marbles, displaying strong effect of dynamometamorphism. It reflects in development of oriented structure in massive and pure calcite types of the marble, and as pronounced foliation and cleavage in mylonitized, mostly impure, silicate marbles. These structures, along with their texture, and mineral composition are governing the pattern of their later brittle deformation, which is responsible for development of fracture and intergranular porosity. Due to the interconnected porosity, the rocks are locally strongly hygroscopic, enabling water circulation. These characteristics play an important role on the way of the rocks' disintegration, and precondition the pattern of their karstification and weathering.

It is evident that the pure limestone contained calcite veins prior to marmorization and recrystallized into coarse-grained marbles. Progressive recrystallization of the rock sequence was followed by ductile to semi-ductile deformations. The calcite grains reflect the impact of cataclasis and mylonitization under direct stress at considerable depths (Fig. 6b in Appendix). Their texture became heteroblastic to porphyroclastic (Fig. $6 \mathrm{~b}$ in Appendix) with the structure oriented and locally foliated (Figs. 201 in Appendix; Fig. 36 in Appendix; Figs. 37-40 in Appendix). This type of deformation is the most evident in the samples from the Ak-Kaya Valley. Due to shear deformations, cleavage fractures developed enabling peeling off of the rock. A local slight folding can be observed in the field that caused interbedding differential slips and/or slips along cleavage planes. The developed weakened zones contribute to the more rapid disintegration of the rock.

In the case of brittle deformation, the purer marbles are competent rock and were therefore strongly affected by fracturing on the macro and micro levels, most often along the previously weakened directions. In the coarsergrained (saccharoid) marbles, microscopic intergranular porosity developed, enabling the capillary suction of water and therefore strong hygroscopicity and sensitivity of the rock to the freeze-thaw effect. As a result, the marble rapidly disintegrates to sandy particles (Fig. 37 in Appendix). The more solid, finer-grained varieties tend to split along pronounced oriented structure and along foliation. In the first case, thicker rock plates (Fig. 38 in Appendix) tend to split from the rock, while in the second case, they can also be very thin. Meta-limestone with chert shows differential weathering. "Armoured" by recrystallized silica, flutes form on rock surfaces with less eroded quartzose hinges and deeper channels in the calcite layers (Fig. 39 in Appendix). Incompetent layers of impure marbles suffered most of the shifting in the course of dynamometamorphism and hence they always have pronounced foliation (Fig. 40 in Appendix; Fig. 20e in Appendix).

The rock relief reveals similar conditions of the karren formation in all three localities. The subsoil formation of the rock and its transformation by rainwater that reaches the rock directly and carves rain flutes and rain pits or creeps down the rock or through it carving channels and co-forming pits, one of the most characteristic forms of these karren, play a visible role here. The water also hollows the rock.

The pits are a composite rock form. In their formation, rainwater, creeping and standing water, biocorrosion, and subsoil formation beneath material brought in by water make their marks in various ratios. On the rock that has been denuded for a longer period, the latter forms can dominate and this is usually so on sunless parts of the rock (Ak-Bom).

Peeling off of the rock imprints the most distinct stamp on the rock relief. The relief developed as a consequence of alternation between the dominant chemical dissolving and mechanical disintegration, which is expressed as peeling off. The variety of peeling is pre-determined by the marbles' structure and texture. The final disintegration reflects an impact of freezing-thaw effect on the moist rock with intergranular and fracture porosity. All three localities are unique. The slope inclination has an important influence on the size of the peeled off layers and on the shape of the karren.

In the Ak-Kaya Valley the manner of peeling off is dictated by the vertical thin layered structure of the tectonized rock. The rock plates are several centimeters thick, usually dissect the wall in a step-like manner, and 
accumulate beneath it. The water flows along cleavage fractures in the rock and perforates it with smaller tubes that are denuded in the process of disintegration. The disintegration is dictated by the fine perforation of the thin layered rock and apparently by the freezing of water in the cavities.

A characteristic example of peeling off of thickly layered rock is revealed in the sunny-side walls of the AkBom. The peeled off rock plates vary in size from square centimeters to several square meters and are relatively thin. In places where rock plates fall off, steps occur. Parts of the rock that protrude from the walls peel off the most distinctly, and therefore the walls are evenly rounded.

At the confluence of the Katun and Chuya rivers, the rock also peels off along fissures following cleavage surfaces. There, the lower parts of the slope of the valley formed. The layers are a few decimeters thick. Interlayer cavities form into which water brings sediment and flowstone is deposited on the ceiling above it. Due to the increasing volume and freezing of the moist sediment in them, the upper layer swells and bursts and at thawing, its pieces slide down the slope, forming gravelly slope sediments.

\section{ACKNOWLEDGEMENT}

The authors acknowledge the financial support from the Slovenian Research Agency (research core funding No. P6-0119 and No. P1-0025), the authors acknowledge the project Research of the Karst and the Development of Karstology in the Altai Republic (with Experience from the Classical Karst), BI RU/16-18-038 was financially supported by the Slovenian Research Agency, research was included in projects: Natural resources of karst show caves: a balance among protection, exploitation, and promotion (J7-7100), LifeWatch-ERIC Research Infrastructure: e-Science European Infrastructure for Biodiversity and Ecosystem Research, in eLTER H2020: Long-Term Ecosystem and socio-ecological Research Infrastructure and in UNESCO IGCP project No. 661.

\section{REFERENCES}

Al Farraj Al Ketbi, A., Slabe, T., Knez, M., Gabrovšek, F., Mulec, J., Petrič, M. \& N. Zupan Hajna, 2014: Karst in Ras Al-Khaimah, northern United Arab Emirates.- Acta carsologica, 43, 1, 23-41. https://doi. org/10.3986/ac.v43i1.579

Buslov, M.M., Geng, H., Travin, A.V., Otgonbaatar, D., Kulikova, A.V., Chen Ming, Stijn, G., Semakov, N.N., Rubanova, E.S., Abildaeva, M.A., Voitishek, E.E. \& D.A. Trofimova, 2013: Tectonics and geodynamics of Gorny Altai and adjacent structures of the Altai-Sayan folded area.- Russian Geology and Geophysics 54, 10, 1250-1271. https://doi.org/10.1016/j. rgg.2013.09.009

Debevec, B., Knez, M., Kranjc, A., Pahor, M., Prelovšek, M., Semeja, A. \& T. Slabe, 2012: Preliminary study for the adaptation of the "Heaven's Cave" for tourist purposes (Phong Nha-Ke Bang National Park, Vietnam).- Acta carsologica, 41, 1, 115-127. https://doi. org/10.3986/ac.v41i1.52

Engelhardt, W., Füchtbauer, H. \& G. Müller, 1964: Sediment-Petrologie, Methoden der Sediment-Untersuchung, Teil 1.- E. Schweizerbart'sche Verlagsbuch- handlung (Nägele u. Obermiller), pp. 303, Stuttgart. https://doi.org/10.1002/iroh.19650500317

Gutiérrez Domech, R., Knez, M. \& T. Slabe, 2015: Felo Pérez Mogote (Viñales, Pinar del Río, Cuba): typical shaping of rock surface below dense tropical vegetation.- Acta carsologica, 44, 1, 47-57. https://doi. org/10.3986/ac.v44i1.680

Knez, M., Otoničar, B. \& T. Slabe, 2003: Subcutaneous stone forest (Trebnje, Central Slovenija).- Acta carsologica, 32, 1, 29-38. https://doi.org/10.3986/ ac.v32i1.362

Knez, M., Liu, H. \& T. Slabe, 2010: High Mountain Karren in Northwestern Yunnan, China.- Acta carsologica, 39, 1, 103-114. https://doi.org/10.3986/ac.v39i1.116

Knez, M., Slabe, T. \& L.E. Panisset Travassos, 2011: Karren on laminar calcarenitic rock of Lagoa Santa (Minas Gerais, Brazil).- Acta carsologica, 40, 2, 357367. https://doi.org/10.3986/ac.v40i2.19

Knez, M., Liu, H. \& T. Slabe, 2012: Major stone forest, litomorphogenesis and development of typical shilin (Yunnan, China).- Acta carsologica, 41, 2/3, 205218. https://doi.org/10.3986/ac.v41i2-3.558 
Knez, M., Rubinić, J., Slabe, T. \& E. Šegina, 2015: Karren of the Kamenjak hum (Dalmatian Karst, Croatia): from the initial dissection of flat surfaces by rain to rocky points.- Acta carsologica, 44, 2, 191-204. https://doi.org/10.3986/ac.v44i2.1546

Knez, M., Slabe, T. \& K. Urushibara-Yoshino, 2017: Lithology, rock relief and karstification of Minamidaito Island (Japan).- Acta carsologica, 46, 1, 47-62. https://doi.org/10.3986/ac.v46i1.2022

Knez, M., Ruggieri, R. \& T. Slabe, 2019: Karren above Custonaci (Sicily, Italy).- Acta carsologica, 48, 1, 4358. https://doi.org/10.3986/ac.v48i1.7029

Marinin, A.M., 1990: Karst and caves of Altai.- Novosibirsk State Pedagogical Institute, pp. 148, Novosibirsk.

Munsell Rock-Color Chart, 2009: Geological Rock-Color Chart.- Munsell Color, Grand Rapids, MI, USA.

Ollier, C., 1984: Weathering.- Longman, pp. 270, London and New York.

Ota, T., Utsunomiya, A., Uchio, Y., Isozaki, Y., Buslov, M.M., Ishikawa, A., Maruyama, S., Kitajima, K., Kaneko, Y., Yamamoto, H. \& I. Katayama, 2007: Geology of the Gorny Altai subduction-accretion complex, southern Siberia: Tectonic evolution of an
Ediacaran-Cambrian intra-oceanic arc-trench system.- Journal of Asian Earth Sciences, 30, 666-695. https://doi.org/10.1016/j.jseaes.2007.03.001

Slabe, T., 1995: Cave Rocky Relief.- Zbirka ZRC 10, pp. 128, Ljubljana.

Slabe, T. \& H. Liu, 2009: Significant subsoil rock forms.In: Gines, A. et al. (eds.) Karst Rock Features - karren sculpturing. ZRC Publishing, pp. 123-137, Postojna - Ljubljana.

Slabe, T., Hada, A. \& M. Knez, 2016: Laboratory modeling of karst phenomena and their rock relief on plaster, subsoil karren, rain flutes karren and caves.- Acta carsologica, 45, 2, 187-204. https://doi.org/10.3986/ ac.v45i2.4623

Turkin, Y., Krivchikov, V. \& S. Fedak, 2004: Tectonic map of Altai Republic, 1:1,000,000.- Federal State Unitary Enterprise "Gorno-Altaisk Search and Survey Expedition", Ministry of Natural Resources of the Russian Federation, Gorno-Altaisk.

Valiy, V. \& E. Strebkov (eds.), 2018: Altai republic, Tourist atlas, Administrative territorial structure, 1:3,000,000.- The Commonwealth, a group of companies, pp. 86, Moscow.

\section{APPENDIX}

Figs. 5-6; Figs. 8-15: Rock pillars in the Ak-Kaya Valley, their rock relief and microscope sections (Fig. 5, Figs. 8-15 (Photo: T. Slabe); Fig. 6 (Photo: M. Trajanova)).

Figs. 19-20; Figs. 22-26: Rock walls in Ak-Bom, their rock relief, and microscope sections (Figs. 19-20c, Fig. 20f, Fig. 20h, Figs. 22-26 (Photo: T. Slabe); Figs. 20d-20e, Fig. 20g, Figs. 20i-20n (Photo: M. Trajanova)).
Fig. 30; Figs. 32-35: Rocky slopes at the confluence of the Chuya and Katun rivers, their rock relief and microscope sections (Figs. 30a-30e, Fig. 30g (Photo: M. Trajanova); Fig. 30f, Figs. 32a-35m (Photo: T. Slabe)).

Figs. 36 to 40: A wall in Ak-Bom and its microscope sections (Fig. 36 (Photo: M. Trajanova); Figs. 37-40 (Photo: T. Slabe)). 

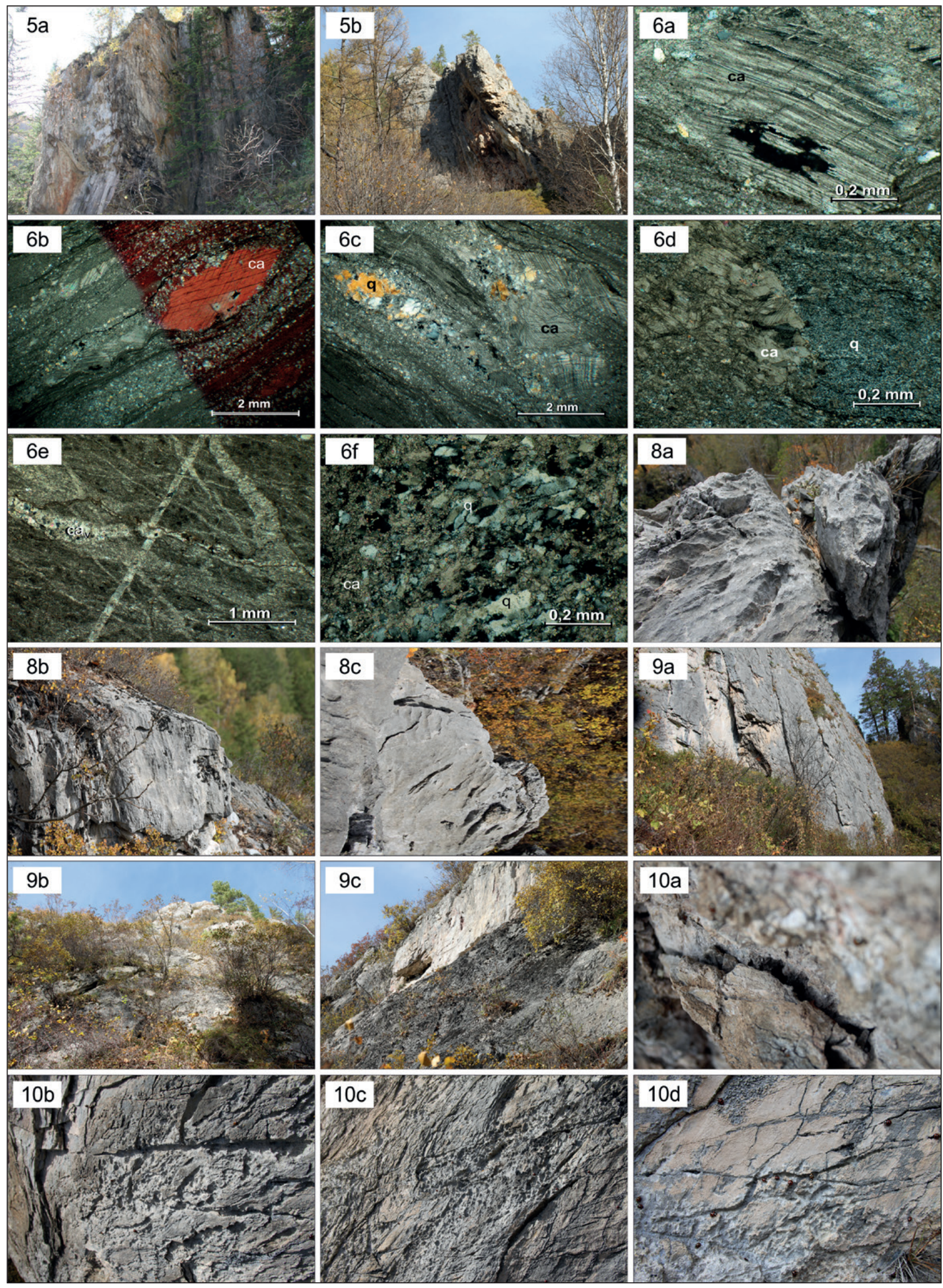

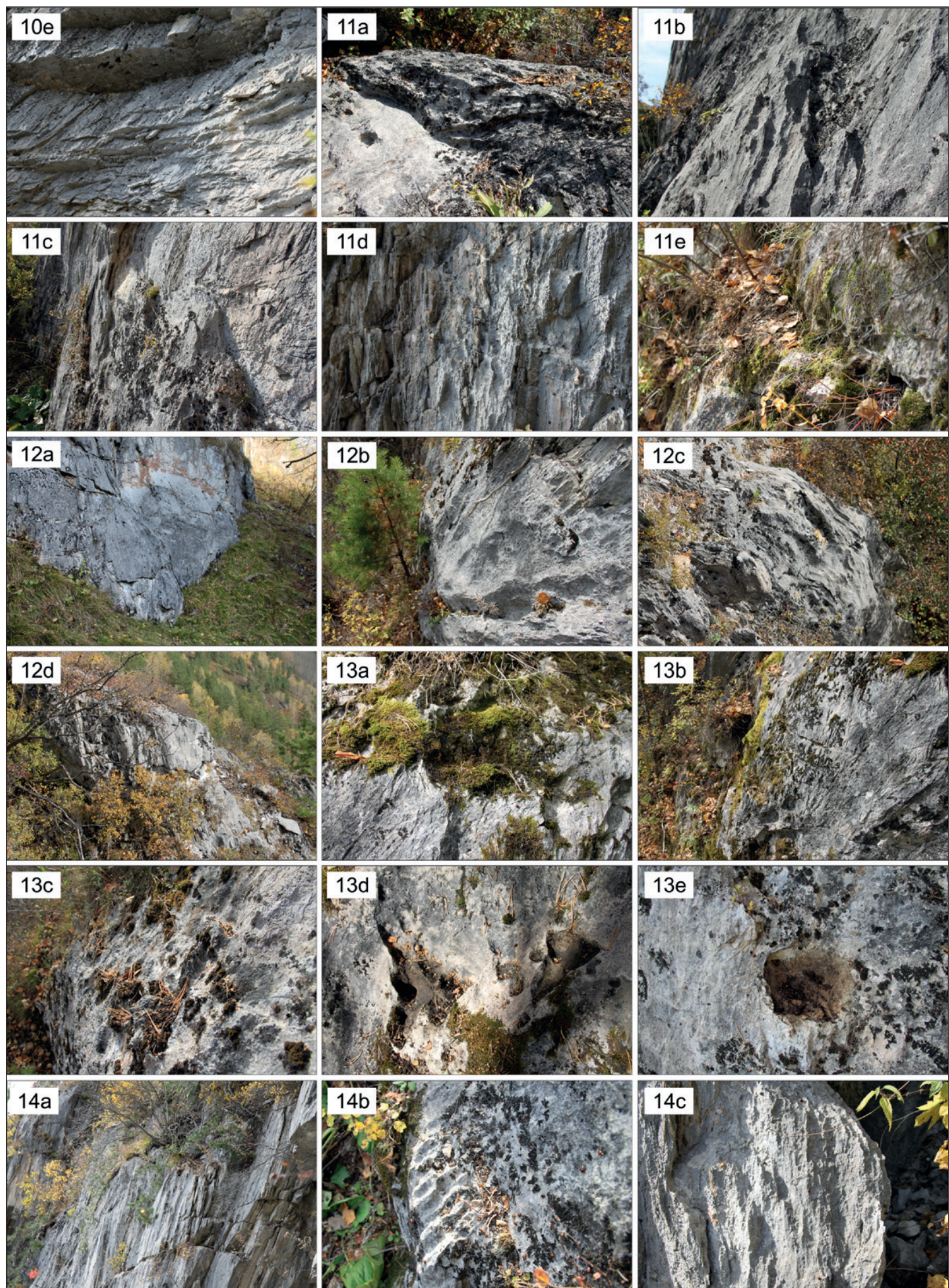

\section{$13 b$}
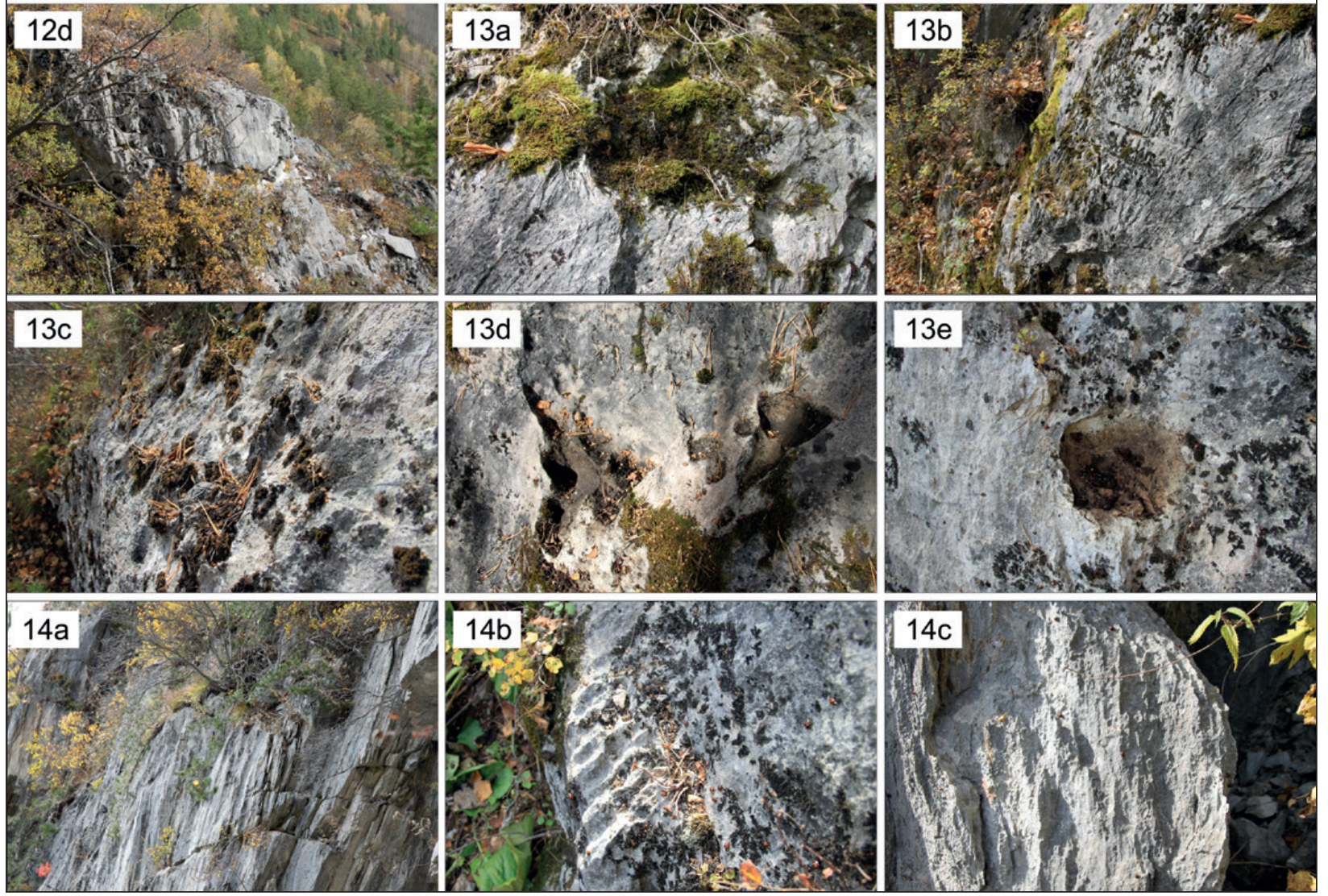

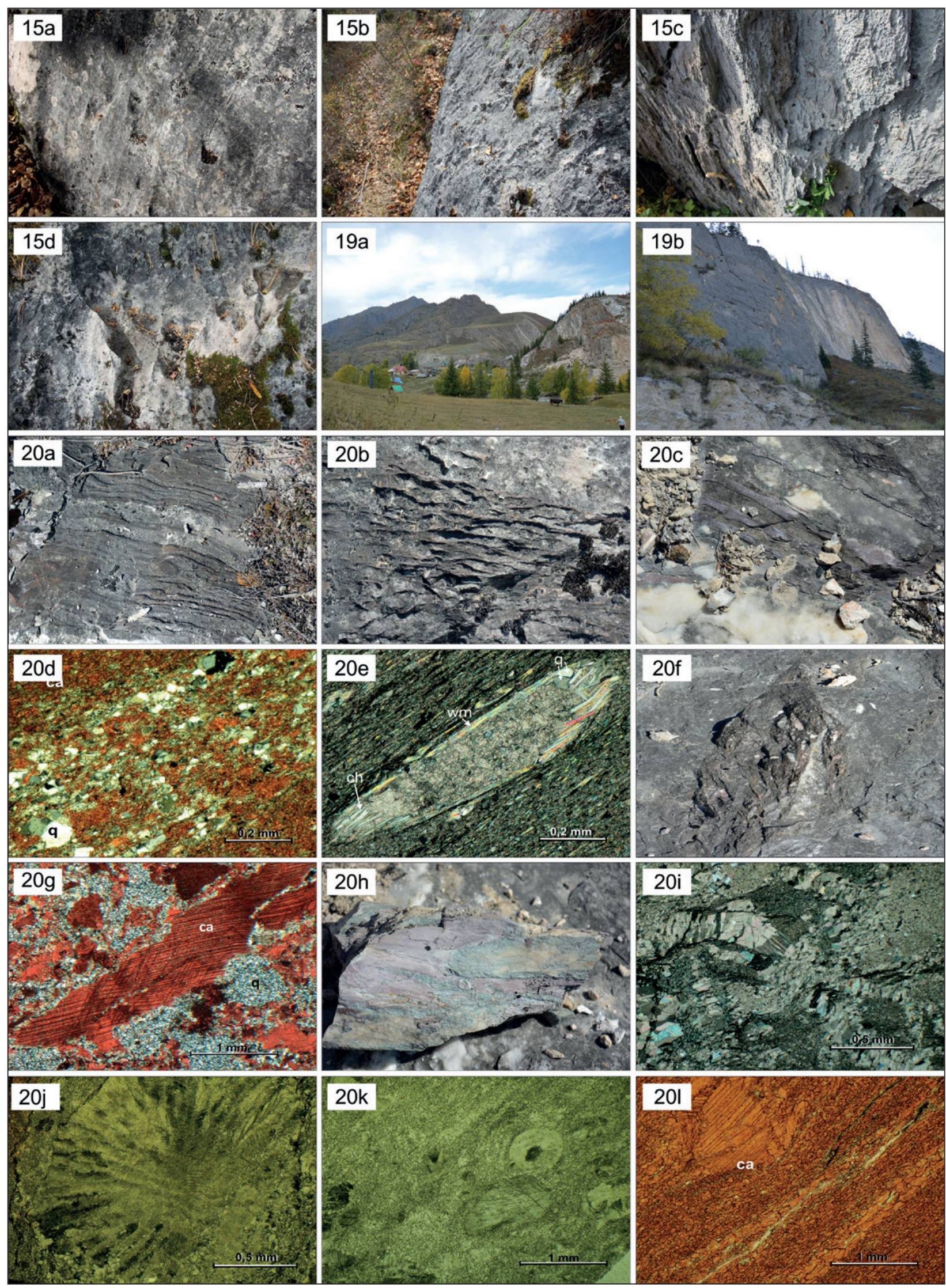

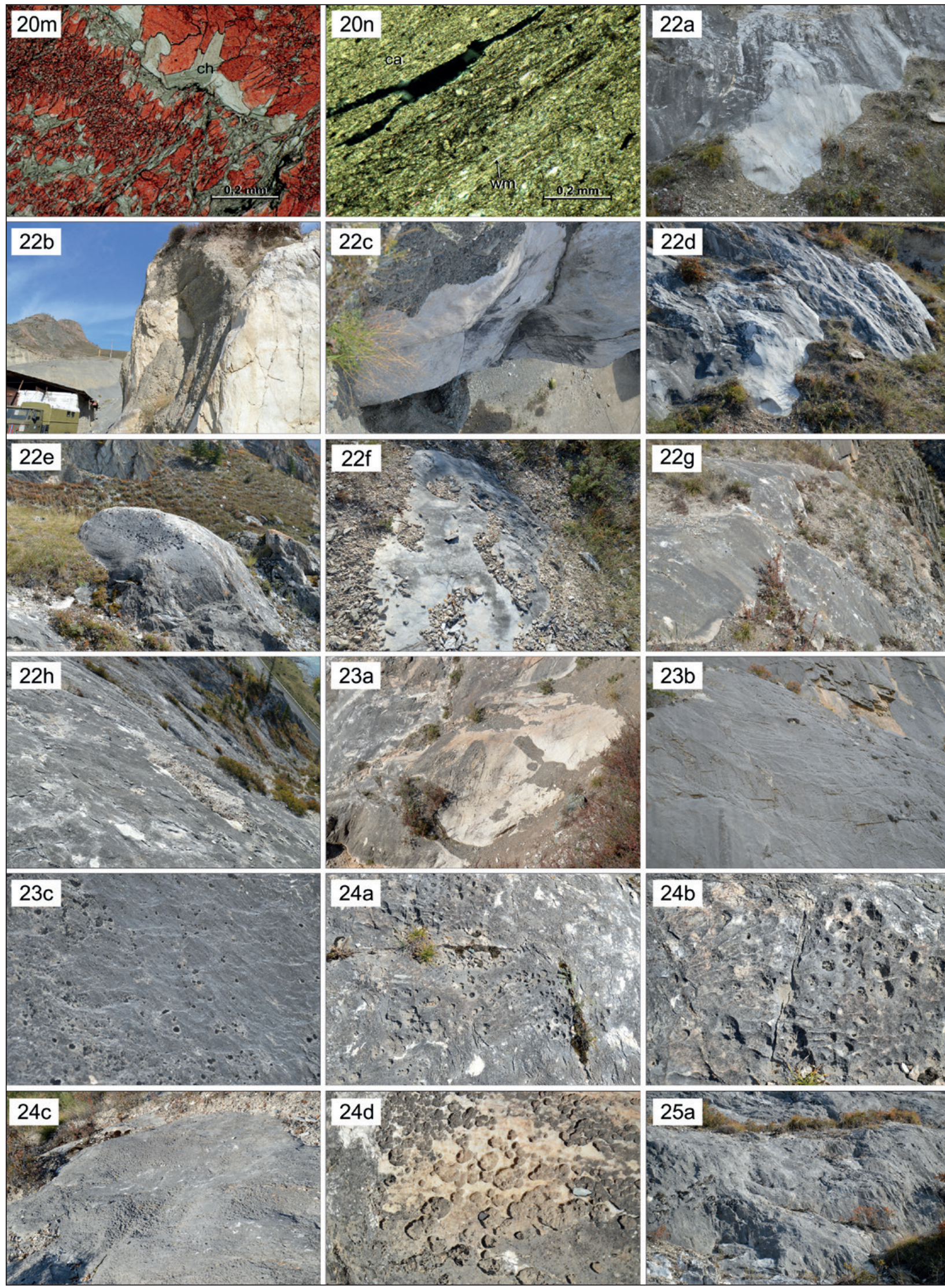


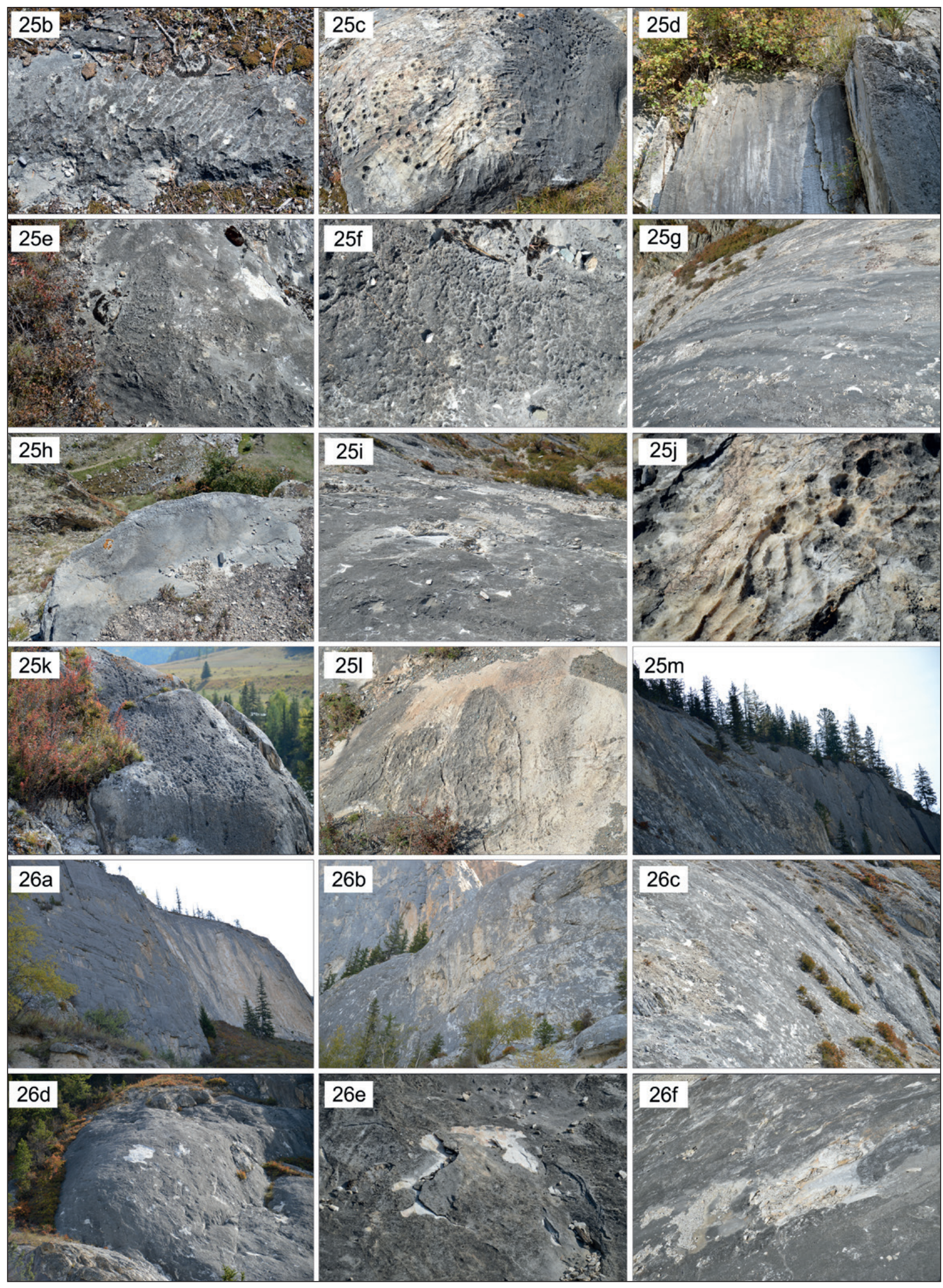




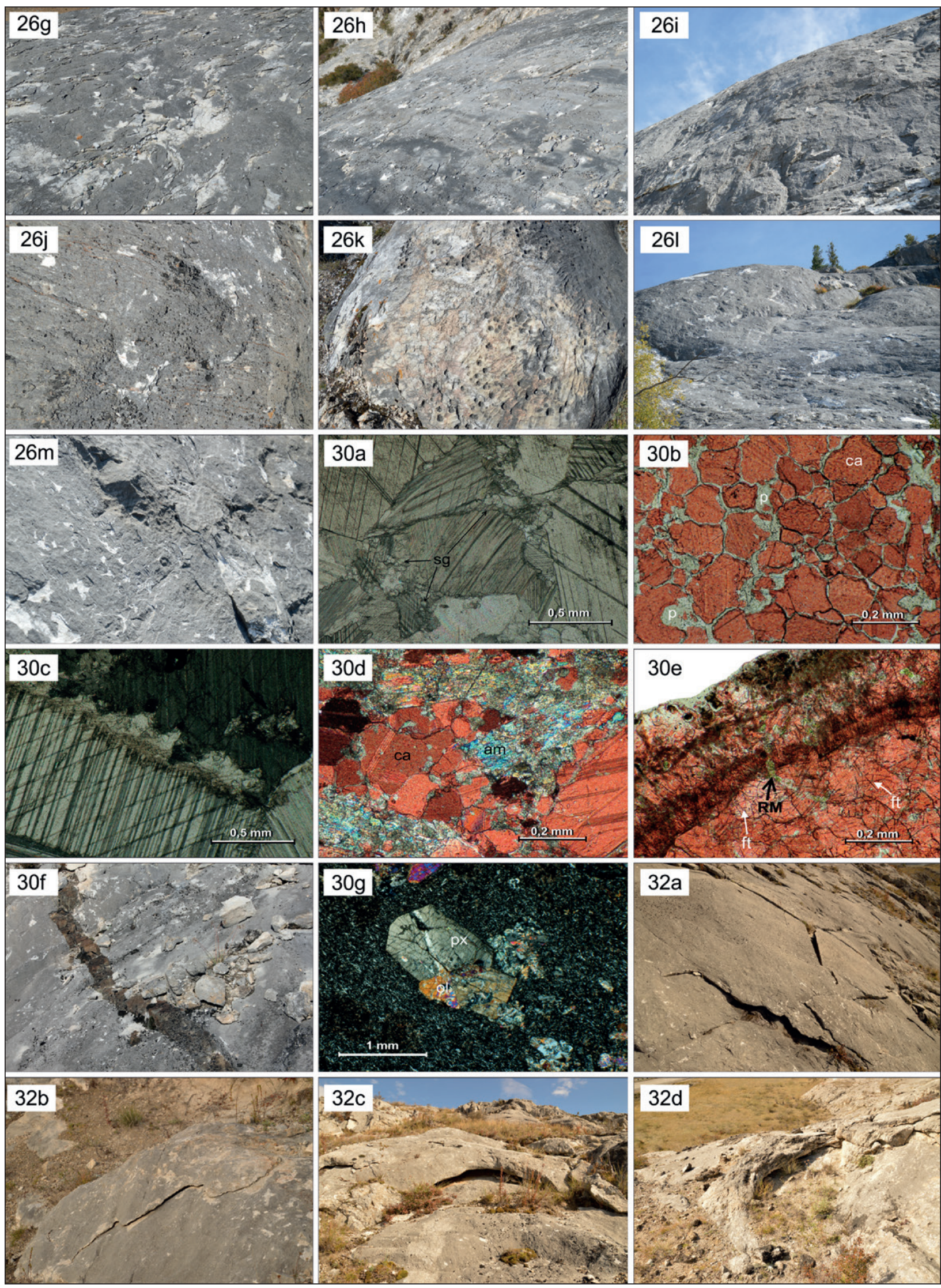




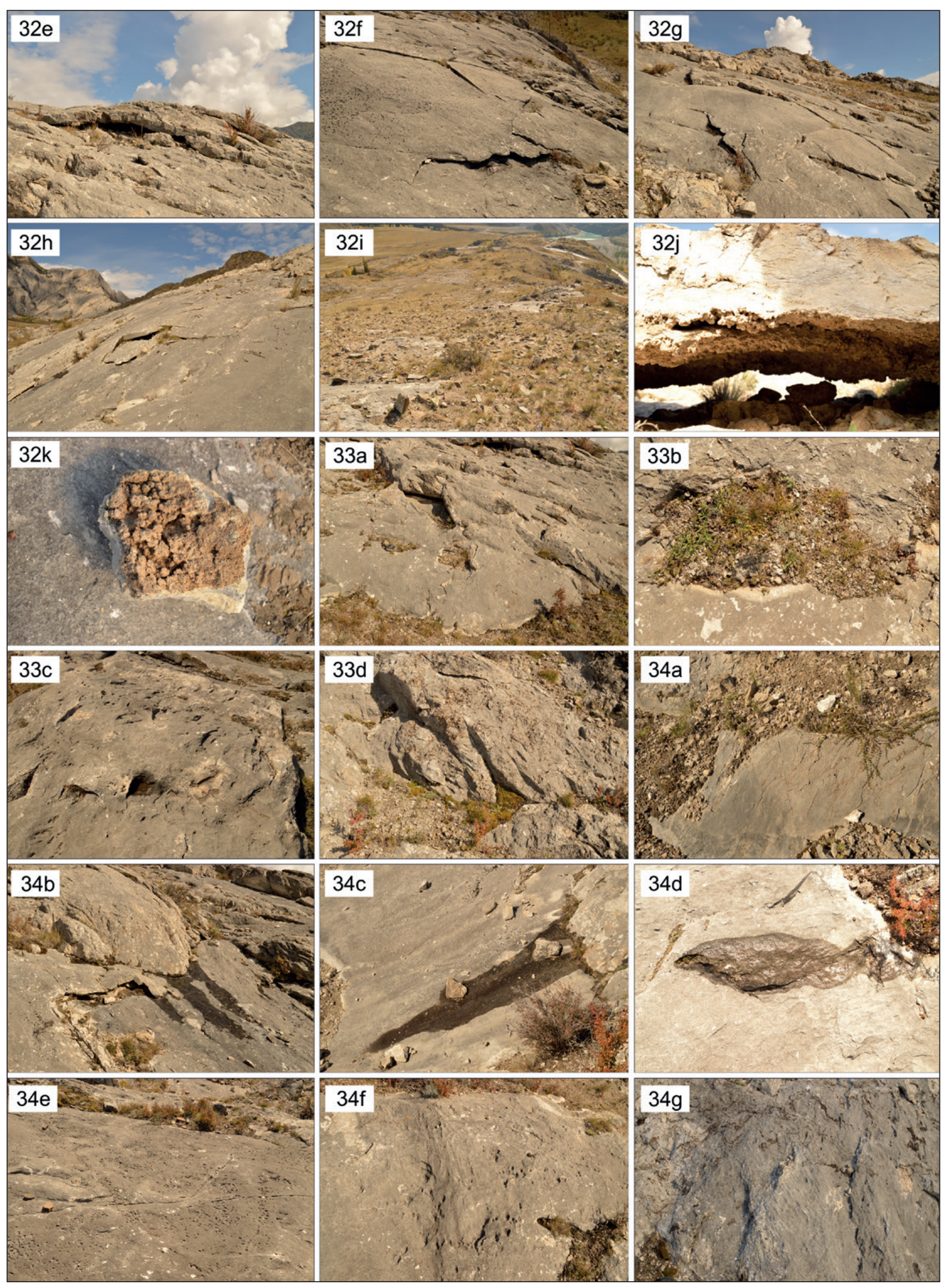




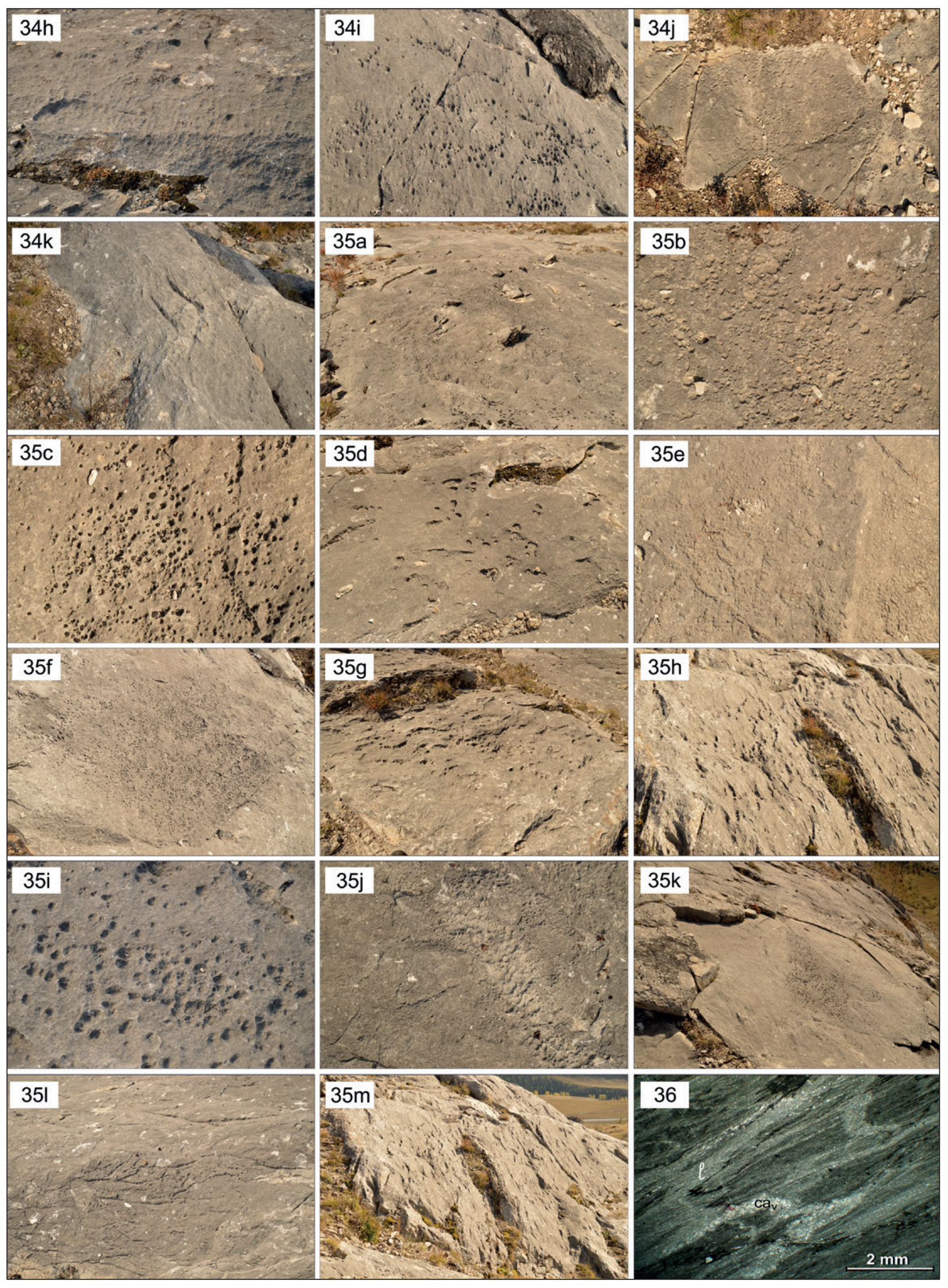



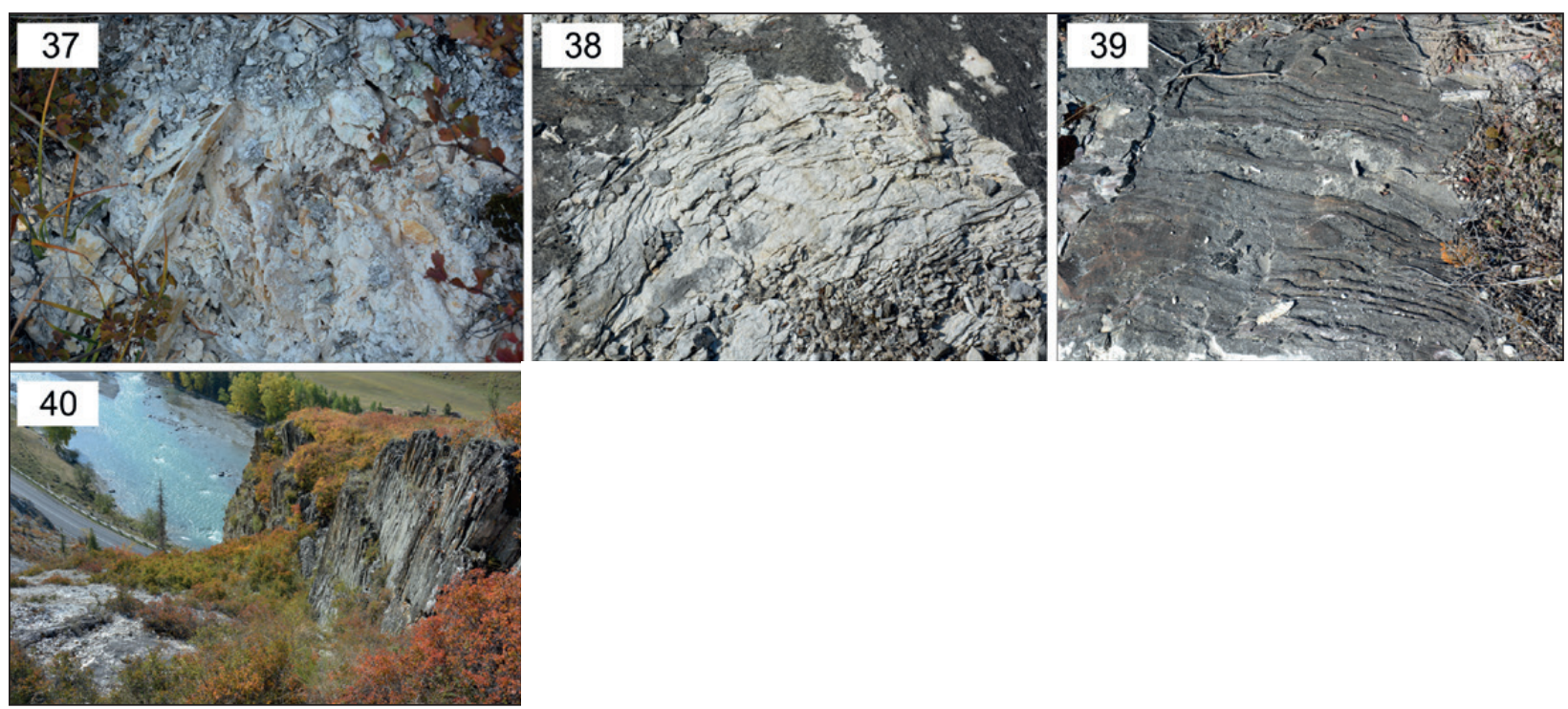